\title{
DIAGNÓSTICO ETNOECOLÓGICO EM COMUNIDADES PESQUEIRAS DO MUNICÍPIO DE CONDE, REGIÃO LITORAL NORTE DO ESTADO DA BAHIA
}

\author{
ETHNOECOLOGICAL DIAGNOSIS IN FISHING COMMUNITIES OF THE \\ MUNICIPALITY OF CONDE, NORTHERN COASTAL REGION OF BAHIA STATE
}

\author{
Eraldo Medeiros Costa Neto ${ }^{1}$, Cássia Tatiana da Silva Andrade ${ }^{2}$, Daniela Fiscina Couto ${ }^{3}$, Henrique Fernandes de Magalhães ${ }^{4}$ \\ ${ }^{1}$ Programa de Pós-Graduação em Ecologia e Evolução, Departamento de Ciências Biológicas, UEFS.; ${ }^{2}$ Bióloga do Laboratório de Etnobiologia e \\ Etnoecologia/UEFS.; ${ }^{3}$ Bióloga. Diretora de Preservação e Controle Ambiental Prefeitura Municipal de Araçás, Bahia; ${ }^{4}$ Pesquisador do Laboratório de Ecologia e \\ Evolução de Sistemas Socioecológicos (LEA/UFPE). Doutorando em Etnobiologia e Conservação da Natureza (UFRPE); *Autor para contato: \\ eraldont@hotmail.com
}

\section{Resumo}

As transformações socioeconômicas que ocorrem nas últimas décadas no Litoral Norte do Estado da Bahia vêm modificando as relações produtivas locais, baseadas na interação direta com a natureza, no acesso à ampla disponibilidade dos recursos naturais e em formas de uso do território que até recentemente eram regulados por normas sociais estabelecidas pelos agrupamentos humanos locais. Situado na porção norte da Área de Proteção Ambiental Litoral Norte, o município do Conde apresenta-se como a principal referência em termos de ocupação de comunidades de pescadores tradicionais. As informações teórico-práticas que os pescadores, marisqueiras e catadores de caranguejos apresentam sobre o comportamento, hábitos alimentares, reprodução e ecologia dos recursos pesqueiros oferece uma rica e desconhecida fonte de informações sobre como manejar, conservar e utilizar os recursos naturais de maneira mais sustentável. Os dados foram coletados no período de setembro de 2007 a dezembro de 2009. Foi priorizada a observação de práticas cotidianas ligadas ao trabalho e à manutenção do grupo doméstico, utilizando técnicas de entrevistas informais e semiestruturadas (seguindo-se roteiro temático e caracterização sociocultural dos sujeitos) com 46 moradores, seguindo preceitos éticos de investigação com seres humanos como prescritos pela Resolução 466/2012 do Conselho Nacional de Saúde. Tendo como base o princípio etnoecológico e a singularidade desta região, recomenda-se a criação de uma rede de articulação comunitária que proporcione às comunidades tradicionais residentes sua efetiva organização, com o fortalecimento de sua representatividade para o município e toda região circunvizinha e a possibilidade de estabelecimento e apropriação do território face ao desenvolvimento turístico e à pesca industrial predatória, por meio da sistematização dos seus conhecimentos etnoecológicos para a elaboração de um plano de manejo sustentado dos recursos pesqueiros. Os resultados poderão contribuir futuramente para o estabelecimento de um mecanismo legal de apropriação deste território por meio da criação da Reserva Extrativista da Planície Flúvio-Marinha do município do Conde, que garantiria a inclusão das populações locais em projetos sustentáveis de geração de renda. Saliente-se que o relatório final produzido por este estudo diagnóstico foi entregue ao presidente da Colônia Z-31 e em cada associação comunitária das povoações visitadas.

Palavras-chave: Atividade pesqueira, Patrimônio biocultural, Turismo, Gestão socioambiental

\section{Abstract}

As transformações socioeconômicas que ocorrem nas últimas décadas no Litoral Norte do Estado da Bahia vêm modificando as relações produtivas locais, baseadas na interação direta com a natureza, no acesso à ampla disponibilidade dos recursos naturais e em formas de uso do território que até recentemente eram regulados por normas sociais estabelecidas pelos agrupamentos humanos locais. Situado na porção norte da Área de Proteção Ambiental Litoral Norte, o município do Conde apresenta-se como a principal referência em termos de ocupação de comunidades de pescadores tradicionais. As informações teórico-práticas que os pescadores, marisqueiras e catadores de caranguejos apresentam sobre o comportamento, hábitos alimentares, reprodução e ecologia dos recursos pesqueiros oferece uma rica e desconhecida fonte de informações sobre como manejar, conservar e utilizar os recursos naturais de maneira mais sustentável. Os dados foram coletados no período de setembro de 2007 a dezembro de 2009. Foi priorizada a observação de práticas cotidianas ligadas ao trabalho e à manutenção do grupo doméstico, utilizando técnicas de entrevistas informais e semiestruturadas (seguindo-se roteiro temático e caracterização sociocultural dos sujeitos) com 46 moradores, seguindo preceitos éticos de investigação com seres humanos como prescritos pela Resolução 466/2012 do Conselho Nacional de Saúde. Tendo como base o princípio etnoecológico e a singularidade desta região, recomenda-se a criação de uma rede de articulação comunitária que proporcione às comunidades tradicionais residentes sua efetiva organização, com o fortalecimento de sua representatividade para o município e toda região circunvizinha e a possibilidade de estabelecimento e apropriação do território face ao desenvolvimento turístico e à pesca industrial predatória, por meio da sistematização dos seus conhecimentos etnoecológicos para a elaboração de um plano de manejo sustentado dos recursos pesqueiros. Os resultados poderão contribuir futuramente para o estabelecimento de um mecanismo legal de apropriação deste território por meio da criação da Reserva Extrativista da Planície Flúvio-Marinha do município do Conde, que garantiria a inclusão das populações locais em projetos sustentáveis de geração de renda. Saliente-se que o relatório final produzido por este estudo diagnóstico foi entregue ao presidente da Colônia Z-31 e em cada associação comunitária das povoações visitadas.

Keywords: Fishing activity, Biocultural heritage, Turism, Socioenvironmental management 


\title{
INTRODUÇÃO
}

\author{
O Bem do Mar \\ Por Dorival Caymmi \\ O pescador tem dois amor \\ Um bem na terra, um bem no mar \\ O bem de terra é aquela que fica \\ Na beira da praia quando a gente sai \\ O bem de terra é aquela que chora \\ Mas faz que não chora quando a gente sai \\ O bem do mar é o mar, é o mar \\ Que carrega com a gente \\ pra gente pescar.
}

O processo de ocupação do litoral brasileiro remonta ao início da colonização do país, mas se estrutura de forma especial a partir do século XX. Por isso mesmo, os conflitos ambientais ao longo da zona costeira são muitos e a transformação da paisagem, drástica. Segundo Macedo e Pelegrino (1996), podem ser definidos dois padrões paisagísticos: aqueles buscados pelos turistas e aqueles explorados pelas indústrias imobiliárias e turísticas. Estes padrões são apontados como os principais fatores de destruição dos recursos paisagísticos e ambientais existentes na linha costeira, uma vez que os ecossistemas aí localizados, como manguezais, dunas, restingas, lagos e lagunas, são extremamente suscetíveis à urbanização e, quando fragmentados e drasticamente subdivididos, tendem a desaparecer.

O Litoral Norte do Estado da Bahia, historicamente ocupado pela agropecuária, apresenta hoje uma rica e dinâmica economia baseada no turismo, que canaliza para os municípios que o compõe, especialmente Mata de São João e Entre Rios, investimentos nacionais e internacionais de grande porte, processo que transformou esta região em um pólo de expressão nacional e internacional, coexistindo com uma economia de pequeno porte, assentada no extrativismo vegetal, na mariscagem e na pesca, principalmente do tipo artesanal.

A agricultura de subsistência remonta à organização social indígena encontrada pelos europeus no início do século XVI, assim como a pesca, a coleta de mariscos e o extrativismo vegetal. Perseverou, tanto ao lado da pecuária extensiva empreendida pela política expansionista da família Ávila, quanto do posterior comércio de coco, e fruticultura em geral, até as atividades mais modernas, como a petrolífera dos anos 1950 e a política nacional de reflorestamento dos anos 1970. Na atualidade, ainda que bastante enfraquecida pelo mais recente agravamento da situação fundiária e pela falta de incentivos para a pequena produção agropecuária, as atividades de subsistência continuam a compor esse cenário plural, caminhando lado a lado com empreendimentos turísticos de grande porte, como o Projeto Sauípe ou o resort construído perto da antiga Torre dos Ávilas (BAQUEIRO et al., 1998).

Em geral, os empreendimentos instalados não têm se comprometido com a conservação dessas áreas, poluindo com o lançamento de esgoto não tratado, com o desmatamento para a construção civil e com o aterramento de zonas úmidas. O crescimento da pobreza, decorrente da exclusão social das populações nativas ao longo do processo histórico de ocupação, vem acarretando também uma forçosa ocupação do ecossistema manguezal tanto por migrantes, em busca de oportunidade, quanto por populações reconhecidas como tradicionais que buscam garantir sua reprodução sociocultural. Além disso, a falta de saneamento básico, como esgotamento, água encanada e coleta de lixo sólido, comprometem o ambiente e a qualidade de vida dessas populações. Soma-se a isso o desconhecimento das práticas tradicionais de captura de mariscos pelos migrantes, instalados mais recentemente na região, intensificando ainda mais a degradação do ecossistema manguezal.

Os esforços até então realizados, como a criação da Área de Proteção Ambiental do Litoral Norte (em 1992) e a elaboração de seu Plano de Manejo (em 1995), por si só não se efetivam enquanto instrumentos de ação e, portanto, não foram suficientes para assegurar a preservação dos recursos naturais e impedir a pressão socioeconômica que degrada as condições de vida das populações tradicionais que habitam a região.

Deve-se considerar também que a elaboração e a execução de leis federais, estaduais e municipais, que visam regulamentar as relações entre os mais distintos grupos humanos e o ambiente natural, com vistas à preservação ambiental, tais como a delimitação de áreas intocáveis ou de uso regulado e o gerenciamento dos recursos hídricos, entre outras ações legais, são medidas que têm 
modificado consideravelmente o cenário rural. Por conta disso, as várias comunidades que habitam tais "paraísos ecológicos" assistem perplexas a essa enxurrada de códigos e normas, e mais do que isso, têm suas vidas modificadas quando os locais que sempre habitaram passam a ser reconhecidos e valorizados por olhares externos das instituições governamentais e não-governamentais, bem como da sociedade civil, como ilhas de preservação. Práticas ancestrais de lidar com a natureza, ancoradas na sustentabilidade, são desvalorizadas diante do conhecimento legal, cientificamente validado. $\mathrm{O}$ ambiente natural se evidencia neste cenário atual; no entanto, a população que ali habita, de invisível, torna-se indesejável (ROCHA, 2002).

Já há algum tempo, admite-se que a melhor forma de explorar os recursos naturais é aquela que emprega o conhecimento tradicional (SACHS, 1995). Esse conhecimento é passado de geração a geração, especialmente pela oralidade, e registrado como símbolos, fonéticas, narrativas, rituais, música e dança (TOLEDO, 1991). O conhecimento ecológico tradicional, ou etnoecológico, fornece uma ferramenta conceitual para um entendimento mais amplo acerca do ambiente, das formas de conhecimento e dos fundamentos epistemológicos que devem ser levados em consideração na busca para um manejo mais sustentável dos recursos naturais (RIST e DAHDOUH-GUEBAS, 2006). Estudos recentes nesta área reconhecem o importante papel das comunidades tradicionais nesse sentido, incorporando conhecimento ao conjunto de informações técnico-científicas disponíveis para subsidiar políticas públicas conservacionistas e o manejo dos recursos (SILVANO e VALBO-JORGENSEN, 2008).

As comunidades rotuladas de tradicionais podem apresentar soluções criativas para equilibrar sua inserção no meio, conciliando produção agrícola alimentar, reprodução social e manutenção ecológica do ambiente, isto é, sustentabilidade (FLEURY e ALMEIDA, 2007). Hoje em dia, qualquer abordagem que trate de desenvolvimento deve levar em conta os estudos etnoecológicos, uma vez que o conhecimento do meio ambiente adquirido ao longo dos séculos pelas populações autóctones constitui um ponto de partida interessante. Desconsiderar a diversidade cultural significa ignorar possibilidades múltiplas no momento de se definir novas estratégias de desenvolvimento (BERGAMASCO e ANTUNIASSI, 1998), pois quando as comunidades locais não são envolvidas no processo, torna-se difícil, se não impossível e mais oneroso para os planejadores e tomadores de decisão, identificar e entender os valores ecológico, social, cultural, econômico e espiritual dos vários componentes que integram o meio ambiente (SALLENAVE, 1994).

No que concerne à atividade pesqueira artesanal, esta requer dos pescadores um conhecimento etnoecológico que possibilite a utilização dos recursos pesqueiros e garanta a sustentabilidade desta práxis (MACHADO-GUIMARÃES, 1995). Marques (1993) afirma que os pescadores portam o saber e o saber fazer relacionados com a estrutura e a função do(s) ecossistema(s) ao(s) qual(is) estão vinculados. O convívio diário do indivíduo com o ambiente aquático, somado à necessidade de exploração, lapidou a experiência do pescador, que é capaz de reconhecer com eficiência a distribuição das espécies exploradas, as variações sazonais na abundância e os movimentos migratórios (DORIA et al., 2008). Estes autores relatam a existência de várias estratégias tradicionais de manejo da pesca aplicadas pela população ribeirinha e a efetividade desse processo foi observada e avaliada em alguns trabalhos, permitindo o surgimento de políticas com melhores chances de sustentabilidade quando consideram o conhecimento tradicional, complementado pelo conhecimento científico.

$\mathrm{Na}$ pesca artesanal, o pescador, sozinho ou em parcerias, participa diretamente da captura usando instrumentos relativamente simples, retirando da pesca a maior parte de sua renda, ainda que sazonalmente possa exercer atividades complementares (DIEGUES, 1988). Em todo território nacional, a pesca artesanal efetuada por comunidades litorâneas e ribeirinhas é de grande importância como fonte de alimento e renda (SILVANO, 2004). Estima-se que os pescadores artesanais fornecem cerca de $40 \%$ a $60 \%$ do pescado marinho (DIEGUES, 1999; HAIMOVICI e KLIPPEL, 2002) e 60\% do pescado nos rios amazônicos (BAYLEY e PETRERE-JÚNIOR, 1989). Apesar destes dados, a pesca artesanal ainda é insuficientemente enfocada e conhecida no país. Por esta razão, torna-se necessário conhecer como as populações tradicionais interpretam e reinterpretam suas tradições e formas de lidar com a natureza, para que essas noções sejam consideradas ao se desenvolver planos de manejo para áreas protegidas e para se manter as estruturas necessárias para que esse equilíbrio com o meio persista, entre elas a disposição das terras e as condições econômicas de reprodução da comunidade (FLEURY e ALMEIDA, 2007).

O conjunto de informações teórico-práticas que os pescadores e marisqueiras apresentam sobre comportamento, hábitos alimentares, reprodução, formas de uso e ecologia dos recursos pesqueiros 
oferece uma rica e desconhecida fonte de informações sobre como manejar, conservar e utilizar os recursos naturais de maneira mais sustentável. Daí a importância de identificar, registrar e documentar este conhecimento por meio das narrativas, experiências e memórias dos atores que as vivenciam. $\mathrm{O}$ estudo integrado dos saberes (corpus), práticas/técnicas de apropriação dos recursos locais (práxis) e crenças associadas (cosmos) torna possível compreender as relações que se estabelecem entre a interpretação, leitura e uso ou manejo da natureza e seus processos (TOLEDO, 1992, 2002; BARRERABASSOLS; TOLEDO, 2005).

\section{O LITORAL NORTE DO ESTADO DA BAHIA}

A Bahia é o Estado brasileiro com maior extensão litorânea, correspondendo a $12 \%$ de todo o litoral do país. Nesses últimos anos, a costa do Estado vem passando por um processo de reconquista de seu território que, em função de suas potencialidades ambientais, tem sido direcionada para o turismo, com importantes repercussões no processo de gestão dos recursos costeiros, ocasionando desníveis entre qualidade de vida e qualidade ambiental em toda a faixa litorânea (LAGE e LOPES, 1999). Neste sentido, necessita-se rediscutir questões de gestão do território e de geopolítica do turismo, uma vez que é sabido que capital internacional vem sendo investido para a viabilização de grandes projetos de resorts ao longo do litoral do Estado. O empreendimento turístico e hoteleiro, embora utilize o discurso ecológico preservacionista e conservacionista, visa apenas à maximização dos lucros e dos resultados em detrimento da natureza, que é transformada em mercadoria que pode ser consumida de forma direta ou indireta (GOMES, 1999).

O Litoral Norte da Bahia, particularmente nas últimas décadas, tem passado por profundas transformações políticas, econômicos, sociais e culturais decorrentes da redefinição de sua inserção no modelo de desenvolvimento globalizado em que o país está inserido (VIANNA e REITERMAJER, 1997). A partir dos anos 1960 reservou-se para esta região a produção de madeira e carvão para suprir o Pólo Petroquímico e também para a implantação de indústria de celulose. No entanto, a expansão do turismo internacional e nacional e as características da paisagem da região provocaram uma redefinição dos projetos do Estado e de empresários. A redefinição econômica da região para o turismo, atividade que tem na natureza seu componente central, produziu por parte do Estado uma ação para ordenar a ocupação local, criando a Área de Proteção Ambiental do Litoral Norte, em 1992.

As profundas mudanças que ocorreram na última década na região agravaram as pressões sobre os ecossistemas existentes no Litoral Norte, acrescendo às ações das comunidades tradicionais atividades com graus variados de impactos produzidos pela indústria do turismo, exigindo medidas com vistas a preservar exemplares da rica natureza que estão ameaçados de extinção ou sujeitos aos intensos processos de degradação. No entanto, a região carece ainda de reflexões abrangentes que procurem dar conta da complexidade existente na relação entre a população e os recursos naturais, sem perder de vista as particularidades locais e de medidas que possam garantir a reprodução do modo de vida dessas comunidades.

Nos últimos anos, a atividade imobiliária e sua consequente descaracterização ambiental têm causado intensas modificações no arranjo social das comunidades locais que residem na porção sul da APA do Litoral Norte, mais precisamente na região costeira pertencente aos municípios de Mata de São João e Entre Rios. As comunidades pesqueiras desta região têm substituído paulatinamente a atividade de pesca por trabalhos relacionados à atividade turística. Como consequência desta substituição, os conhecimentos tradicionais sobre as artes de pesca e as formas de manejo sustentado dos recursos pesqueiros estão sendo perdidos ao longo das gerações.

Comunidades que dependiam do livre acesso aos recursos naturais tiveram suas vidas modificadas pelos grandes projetos turísticos que vêm paulatinamente ocupando toda a porção do litoral norte do Estado. As mudanças que se deram no espaço físico, na privatização de lagoas, praias e matas, tiveram efeito significativo na reprodução da família camponesa que vem tendo sua cultura ameaçada e modificada pela introdução de novos hábitos, valores e padrões, característicos das sociedades urbanas e industriais. Em vista disso, projetos que visam à conservação têm que considerar a realidade dessas populações para que não se constituam em mais um instrumento de exclusão social.

$\mathrm{Na}$ atualidade, principalmente nas áreas ainda conservadas do ponto de vista ambiental, situadas no extremo norte da região, pode-se verificar boa parte da população com práticas produtivas ainda em estreita relação e dependência com os ambientes flúvio-estuarino e marinho. Um estudo realizado na comunidade pesqueira de Siribinha, município de Conde, chama a atenção para o saber acumulado ao longo de gerações por pescadores que desenvolveram um sofisticado conhecimento sobre os peixes, que 
inclui desde aspectos de ecologia e taxonomia a aspectos etológicos e utilitários diversos (COSTANETO, 2001). Para o autor, o conjunto de informações teórico-práticas que os pescadores apresentam sobre comportamento, hábitos alimentares, reprodução e ecologia dos peixes oferece uma significativa fonte de informações sobre como manejar, conservar e utilizar os recursos ícticos de maneira sustentável. No entanto, todo esse conhecimento acumulado a respeito da ecologia estuarino-marinha e do comportamento das espécies de importância comercial, referencial necessário para a preservação, encontra-se ameaçado pelo novo modelo econômico.

Diversos autores têm registrado mudanças culturais, sociais e ambientais decorrentes da atividade turística em comunidades de pescadores artesanais brasileiros (ROBBEN, 1982; CASTRO, 1988; MACHADO-GUIMARÃES, 1988; JESUS e NASCIMENTO JÚNIOR, 1996; FIGUEIREDO, 1996; REITERMAJER, 1996; MENDONÇA, 1996; MACEDO e PELEGRINO, 1996; MENEZES e SANTIAGO, 1997; VIANNA e REITERMAJER, 1997; DIEGUES, 1997; QUEIROZ, 1997; MAGALHÃES et al., 2012; SILVA e COSTA NETO, 2018). Por exemplo, em Pontal do Coruripe, Alagoas, o turismo regional provocou profundas mudanças socioculturais, uma vez que as relações marido-mulher foram transformadas com a crescente participação de mão-de-obra feminina, quando as mulheres começaram a receber salários por trabalharem nas pousadas e casas de veranistas como cozinheiras, faxineiras e serventes; jangadas foram substituídas por barcos a motor; a chegada da eletricidade estimulou a compra de eletrodomésticos (ROBBEN, 1982). Como salientado por este autor, "o turismo tornou as pessoas estranhas em sua própria vila".

Estudos até então feitos na região da APA Litoral Norte, em sua maioria, têm sido realizados às custas das exigências do CONAMA, para o cumprimento da lei, tais como os EIA-RIMA, porém não realizam uma avaliação integrada. Além do mais, sendo um instrumento para dar conhecimento sobre os impactos possíveis dos empreendimentos propostos e medidas que minimizem os impactos negativos de determinado empreendimento, não têm valor normativo e, portanto, não garantem a realização das medidas apontadas. Novos projetos devem contemplar a indicação de alternativas que permitam a compatibilização do uso dos recursos naturais e sua conservação, tais como as reservas extrativistas associadas a unidades de conservação de proteção integral.

Utilizando-se critérios de representatividade, importância ecológica, extensão, ocorrência de espécies raras e/ou ameaçadas de extinção, o programa desenvolvido para a análise e refinamento do plano de manejo da APA Litoral Norte definiu que esta área encontra-se incluída em um grupo de dez áreas (top ten) que devem ser prioritárias para a conservação devido a sua grande importância ecológica nesta porção do litoral (BAHIA, 2001).

Tendo como base o princípio etnoecológico e a singularidade desta região, recomenda-se a criação de uma rede de articulação comunitária que proporcione às comunidades tradicionais residentes sua efetiva organização, com o fortalecimento de sua representatividade para o município e toda região circunvizinha e a possibilidade de estabelecimento e apropriação do território face ao desenvolvimento turístico e à pesca industrial predatória, por meio da sistematização dos saberes etnoecológicos com vistas à elaboração de um plano de manejo sustentado dos recursos pesqueiros. Os resultados poderão contribuir futuramente para o estabelecimento de um mecanismo legal de apropriação deste território por meio da criação da Reserva Extrativista da Planície Flúvio-Marinha do município do Conde, projeto este gerado em meados de 2001 e que se encontra arquivado por falta de avanços na articulação dos diagnósticos até hoje realizados. A criação da Resex Flúvio-Marinha do município do Conde "garantiria a inclusão das populações locais em projetos sustentáveis de geração de renda” (BAHIA, 2001).

\section{MATERIAL E MÉTODOS \\ Área de Estudo}

À época de sua colonização, o território municipal de Conde recebeu a denominação de Itapicuru de Baixo (no idioma Tupi, itapicuru significa laje formada de seixos ou protuberâncias). Em 1621, Garcia D'Ávila concedeu a sesmaria aos jesuítas, que construíram uma capela dedicada à Nossa Senhora sobre uma pequena elevação. Em 1792, o povoado foi elevado à categoria de freguesia com o nome de Nossa Senhora do Monte de Itapicuru da Praia para finalmente, em 1806, por ordem do Conde dos Arcos, ser elevada à categoria de Vila. A categoria de cidade só foi reconhecida em 30 de março de 1938 (COSTA-NETO, 2001).

A cidade do Conde situa-se na região norte do Estado da Bahia, cujas coordenadas geográficas

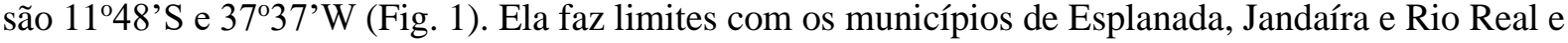
com o Oceano Atlântico. Apresenta um clima úmido a subúmido e úmido, uma temperatura média de 
$25,4^{\circ} \mathrm{C}$, uma pluviosidade anual média de $1.412 \mathrm{~mm}$ e uma vegetação constituída de formações pioneiras com influência flúvio-marinha (mangue) arbórea, formações pioneiras com influência marinha (restinga) arbórea e contato cerrado-floresta estacional (CENTRO DE ESTATÍSTICA E INFORMAÇÕES, 1994).

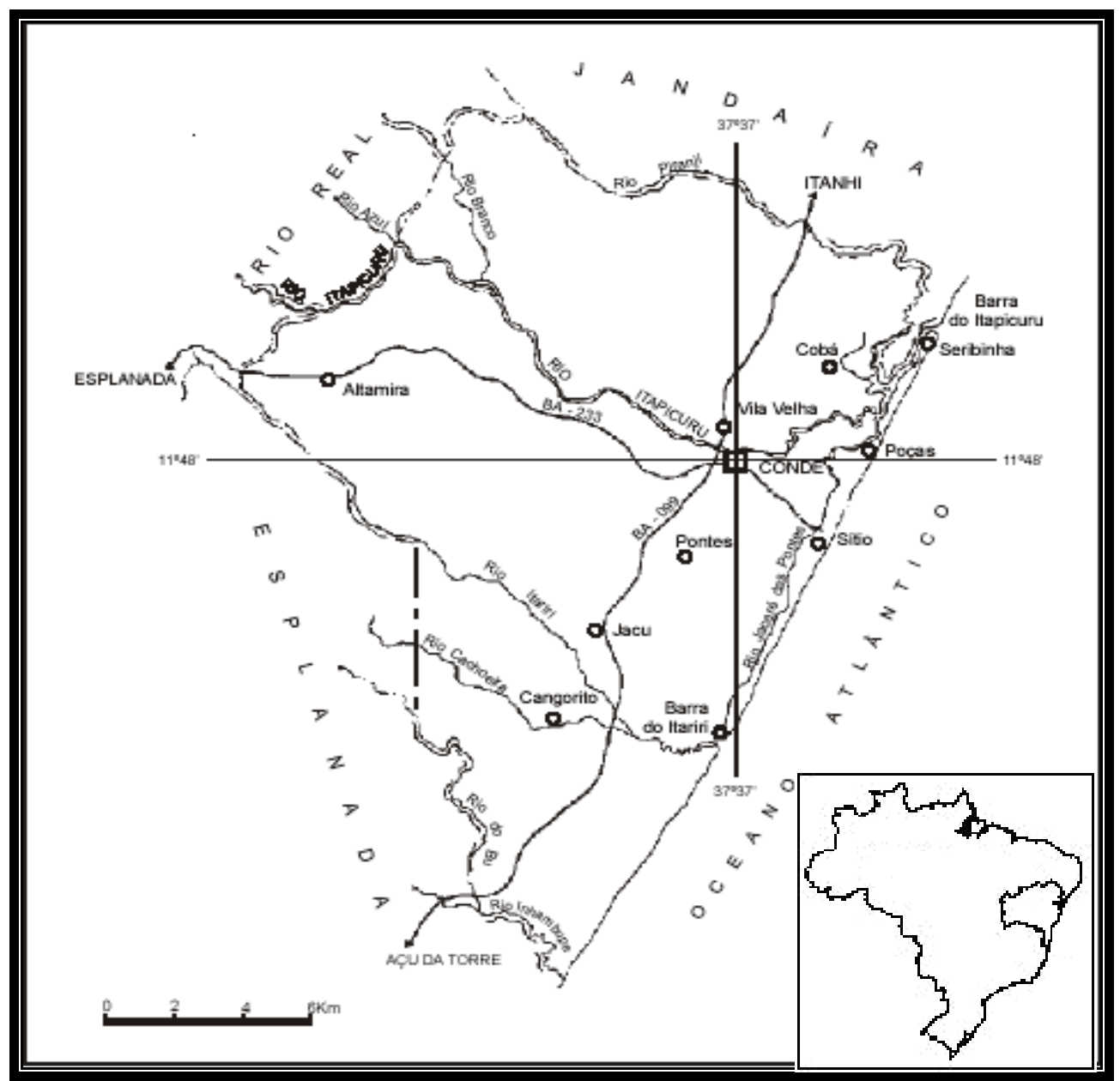

Figura 1: Localização do município de Conde, Bahia.

Conhecida como o "Pantanal baiano", a região comporta 40 quilômetros de praias, dunas, rios, brejos, lagoas e estuários, constituindo-se no que Blandin e Lamotte (1988) conceituam de ecocomplexo, ou seja, um conjunto de ecossistemas interligados (naturais ou modificados) que têm uma história ecológica e antrópica comum e que apresenta novas propriedades emergentes. Essa grande variedade de ecossistemas confere à região uma vasta diversidade biológica (DIEGUES, 2002). A área de estudo inclui-se no domínio da APA Litoral Norte, mais precisamente na porção estuarina e costeira do baixo curso do Rio Itapicuru.

A economia do município baseia-se no comércio, prestação de serviços e extrativismo, com destaque para: indústrias de pequeno porte, tais como madeireiras, perfumarias, sabões e velas, tecidos e produtos alimentares; culturas agrícolas, como coco, banana, mamão, limão, arroz, mandioca, tomate e milho; criação de gado bovino. As atividades de pesca do tipo artesanal sobressaem-se pelo fornecimento significativo de recursos pesqueiros, estando o segmento traduzido por duas atividades distintas: a pesca e a mariscagem (CEI, 1994).

\section{Procedimentos metodológicos}

Os estudos e intervenções que se dedicam a pensar e compreender os grupos sociais que dependem diretamente dos recursos naturais para a sua sobrevivência - a exemplo de pescadores, pequenos agricultores etc. - destacam a importância de atentar para os conhecimentos locais produzidos no contato direto com o ambiente ao se planejar e definir intervenções nestes espaços. Desta forma, é fundamental considerar as práticas que configuram o modo de vida desses grupos, chamando a para o 
universo simbólico subjacente, para as categorias e regras mediante as quais pensam e vivem suas existências (ROCHA, 2002).

No âmbito das localidades prioritárias, as ações contempladas por este estudo foram direcionadas a públicos específicos, de forma a maximizar o impacto social das ações e estimular a difusão dos conhecimentos produzidos ou reunidos em relação ao ambiente por meio do tecido social. As entidades de classe que congregam trabalhadores(as) em atividades mais dependentes do meio ambiente nas localidades definidas como prioritárias para estudo, como colônias, cooperativas ou associações de pescadores e marisqueiras, foram contempladas pelas ações da pesquisa. A relação estreita entre pescadores e marisqueiros e o meio ambiente na esfera da relação de produção, configuraos enquanto atores importantes na construção do saber sobre este ambiente.

Para tanto, foram visitadas nove comunidades pesqueiras: Barra do Itariri, Buri, Poças, Siribinha, Sítio do Conde, Vila do Conde, Cobó, Sempre Viva e Ilha das Ostras. O estudo foi executado em duas fases. Em um primeiro momento, foi realizada uma pesquisa bibliográfica, procedendo-se ao levantamento dos estudos já realizados na área, resultando na sistematização das informações obtidas sobre a região e as comunidades locais. Posteriormente, realizou-se um estudo etnográfico para identificar os usos e significados atribuídos à natureza, conhecer as concepções culturais em torno dos recursos pesqueiros e analisar os usos associados a essas representações. Buscou-se registrar e sistematizar o conhecimento local ${ }^{1}$ por meio do acompanhamento sistemático das comunidades consideradas prioritárias para a execução do estudo, que dependem da conservação dos ecossistemas dos quais fazem parte, escolhidas estrategicamente em relação às áreas ainda conservadas.

O trabalho de campo foi desenvolvido no período de setembro de 2007 a dezembro de 2009. Foi priorizada a observação de práticas cotidianas ligadas ao trabalho e à manutenção do grupo doméstico, utilizando técnicas de entrevistas informais e semiestruturadas (seguindo-se roteiro temático e caracterização sócio-demográfica dos sujeitos) com 46 moradores e informantes-chave (pescadores, marisqueiras e catadores de caranguejo). Os depoimentos foram registrados em micro-gravadores digitais e posteriormente transcritos para cadernos de campo.

Foi utilizado aparelho GPS (Global Positioning System) para georreferenciar as áreas de estudo e os locais onde ocorrem as atividades de pesca. Máquina fotográfica digital foi usada para documentar o ambiente e as interações dos indivíduos com os recursos naturais locais, com isto gerando-se "fragmentos sequenciais" de uma etnografia visual (HARPER, 2000) que visa à observação através de fotos de algumas atividades rotineiras dos entrevistados.

Os indivíduos entrevistados não foram considerados como objetos de pesquisa, mas participantes da pesquisa. Assim, todos tiveram o direito de saber sobre o quê consistia a pesquisa, para quê as informações destinavam-se e qual a finalidade do trabalho. A obtenção dos dados esteve em consonância com a Resolução 196/96 do Conselho Nacional de Saúde que define as diretrizes e normas regulamentadoras de pesquisas envolvendo seres humanos, utilizando Termo de Consentimento Livre e Esclarecido. Respeitou-se a decisão daqueles que não quiseram participar da pesquisa e daqueles que decidiram se retirar em qualquer fase da mesma sem penalização alguma e sem prejuízo à sua pessoa. Foram expostos, muito claramente, quais eram os desconfortos, riscos e benefícios esperados pelo desenvolvimento da pesquisa.

A técnica de turnê (SPRADLEY e MCCURDY, 1972) foi empregada, na qual o pesquisador segue por uma trilha determinada pelo sujeito da pesquisa, enquanto este discorre sobre os elementos que estão sendo observados.

Espécimes de peixes, moluscos e crustáceos, doados pelos próprios pescadores, foram levados ao Laboratório de Etnobiologia e Etnoecologia para uma primeira triagem. Esses animais foram identificados por especialistas e encontram-se depositados na coleção científica do Museu de Zoologia da UEFS.

Os dados foram analisados segundo o modelo de união das diversas competências individuais (HAYS apud MARQUES, 1991), considerando-se toda e qualquer informação registrada. Os controles foram feitos através de testes de verificação de consistência e de validade das respostas (MARQUES, 1991), recorrendo-se a entrevistas repetidas em situações sincrônicas e diacrônicas. As primeiras

${ }^{1}$ Entre outros, situa-se o conhecimento local sobre o ciclo reprodutivo de diversas espécies, o que pode permitir elaborar uma classificação e identificação de formas de uso dessas espécies. Destaca-se também o conhecimento sobre fatores que afetam a dinâmica reprodutiva dos ecossistemas e os fatores naturais que intervêm nessa dinâmica. 
ocorrem quando uma mesma pergunta é feita a pessoas diferentes em tempo bastante próximo e as segundas, quando uma pergunta é repetida à mesma pessoa em tempos bem distintos. A consistência e a robustez do conhecimento tradicional foram observadas mediante a construção de tabelas de cognição comparada, nas quais trechos das entrevistas são comparados com trechos da literatura referente ao bloco de informação citada.

O relatório final produzido por este estudo diagnóstico foi entregue ao presidente da Colônia Z31 e em cada associação comunitária das povoações visitadas.

\section{RESULTADOS E DISCUSSÃO}

\section{Recursos pesqueiros registrados em Conde}

Em um estudo etnoictiológico realizado em 1997-1998, foi possível registrar a ocorrência de um número razoável de peixes, classificados em 17 ordens, 42 famílias, 63 gêneros e 57 espécies. Isto fornece uma ideia da diversidade ictiofaunística presente no Litoral Norte da Bahia, assim como de sua importância para os ecossistemas e comunidades locais. Muitas dessas espécies têm ao menos algum valor de mercado direto ou fazem parte de teias alimentares que suportam recursos economicamente importantes, ou ainda vivem em ambientes cujo bom estado é essencial para a realização das atividades de pesca (COSTA-NETO, 2001).

A família Ariidae se destaca na APA Litoral Norte pelo elevado valor comercial nas vilas de Poças e Siribinha. Bagre bagre (L., 1766), Bagre marinus (Mitchill, 1815) e Arius grandicassis Valenciennes, 1840 apresentam "status" de peixes de primeira. São pescados de forma artesanal e comercializados em média por $\mathrm{R} \$ 10,00$ o quilo (Primo et al., 2005). Estes bagres se destacam na pesca estuarina, sendo diferenciados nos desembarques pela coloração e número de barbilhões.

Além dos peixes, sobressaem-se espécies de moluscos (bivalves e gastrópodes) e crustáceos (camarões, caranguejos e siris) de importância econômica. As mulheres coletoras de mariscos, ou marisqueiras, comercializam apenas duas espécies de moluscos: Anomalocardia brasiliana (Gmelin, 1791) e Pomacea cf. lineata (Spix, 1927), além do crustáceo aratu (Goniopsis cruentata Latreille, 1803) e peixes de pequeno porte. Na etnotaxonomia dos pescadores e marisqueiras de Conde, o termo "marisco" refere-se a crustáceos (camarão, caranguejo, aratu e siri), moluscos (como a ostra) e até uma espécie de coral conhecido localmente como pedra-de-sereia.

No período que compreendido pela pesquisa, o molusco mais explorado comercialmente foi o bivalve localmente conhecido como maçunim (A. brasiliana) devido à abundância na foz do Rio Itapicuru. Pomacea lineata, popularmente conhecida como aruá, é pouco explorada, sendo comercializada em menor escala ou capturada apenas para alimentação (Fig. 2a). Algumas marisqueiras informaram a presença de outras espécies, como Tagelus plebeius (Lightfoot, 1786) (unha-de-velho), Crassostrea sp. (ostra), que não são coletados nem comercializados, e uma espécie (não identificada) de gastrópode marinho coletado apenas para consumo (Fig. 2b).

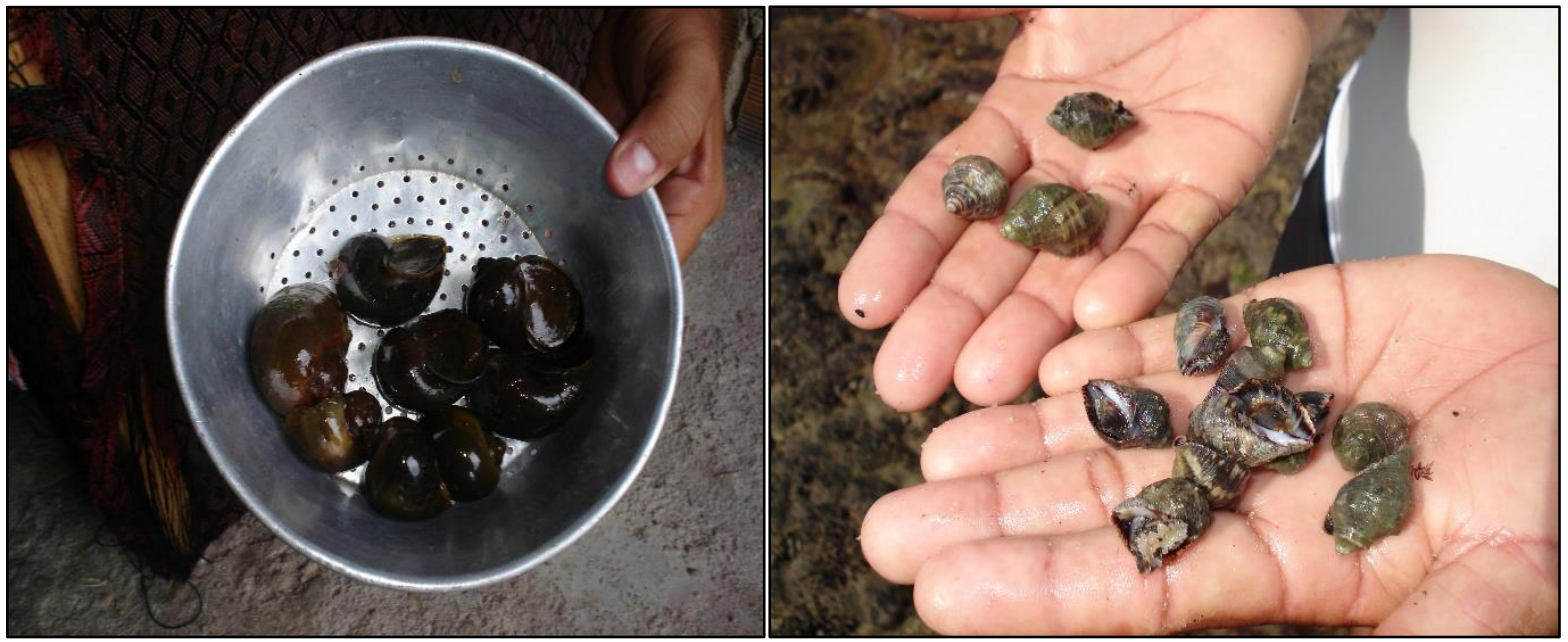

Figura 2a: Aruás coletados no brejo de Sítio do Conde (esq) e 2b Moluscos gastrópodes coletados na praia de Poças (dir).

Dentre os crustáceos, o caranguejo-uçá (Ucides cordatus Linnaeus, 1763) é um dos recursos mais extraídos da região, especialmente nas comunidades do Cobó, Buri, Sempre Viva e Poças, gerando 
renda às famílias que dependem diretamente deste recurso pesqueiro (Fig. 3). Os catadores capturam este caranguejo nos manguezais na planície flúvio-marinha nos períodos de baixa-mar para consumo e venda. Estes trabalhadores possuem um conhecimento elaborado acerca do comportamento da maré, dada sua importância como fator regulador da atividade de "catação" (DIAS e ROSA, 2005; GÓES et al., 2005). No entanto, os catadores de caranguejos são grupos economicamente marginais, extremamente pobres e pouco reconhecidos entre outros pescadores artesanais (FISCARELLI e PINHEIRO, 2002; ALVES e NISHIDA, 2003).
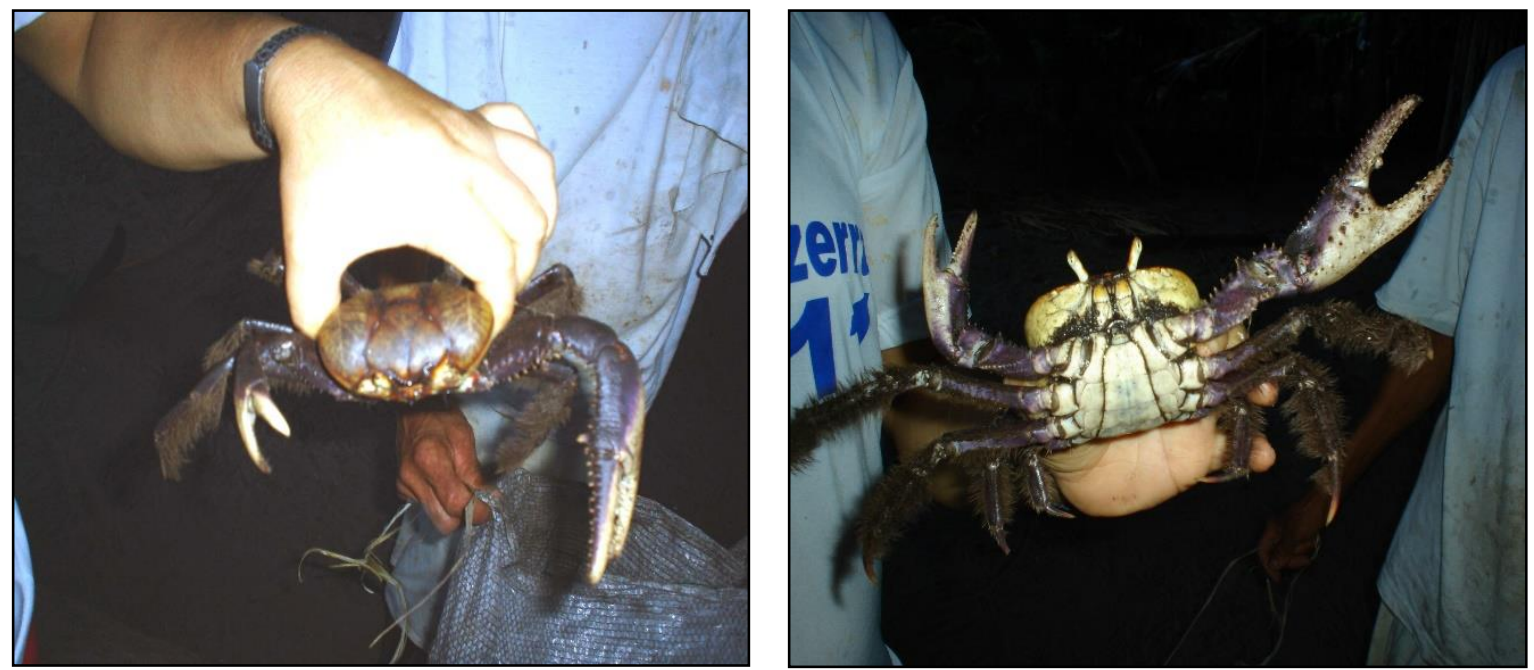

Figura 3. Caranguejo-uçá.

O caranguejo-uçá apresenta uma ampla distribuição geográfica ao longo do Atlântico Ocidental, desde a Flórida até o Sul do Brasil, do Pará até Santa Catarina. Considerada uma espécie-chave nos ecossistemas de manguezal, possui uma importância econômica ímpar como recurso alimentar de subsistência em larga escala para as populações ribeirinhas, movimentando milhões de reais por ano na economia formal e informal devido ao seu elevado consumo, principalmente na região Nordeste (CARQUEIJA, 2005).

Segundo Pereira e Mourão (2004), a previsibilidade e abundância relativa, pouca sazonalidade, baixo capital exigido para a captura e boa aceitação comercial, contribuem para a intensificação da coleta, características que também aumentam o risco de que a exploração a níveis predatórios aconteça, principalmente porque não possibilita, como em outros tipos de pesca, a prática do segredo e manejo de informações que estabelecem direitos de propriedades por meios de territórios de pesca que claramente operam para reduzir incertezas. É preciso estabelecer cooperação entre catadores, órgãos governamentais e não-governamentais para que haja convergência nas ações e na construção e implementação de políticas públicas para proteger o caranguejo-uçá. Além do uçá, registram-se o gaiamum (Cardisoma ganhumi Latreille 1825), siris (Portunidae) e camarões de água doce e salgada (Fig. 4).

Trabalho realizado por Santana et al. (2000) sobre desembarque pesqueiro registrou a presença de 79 espécies de peixes, pertencentes a 46 gêneros de 26 famílias, das quais Lutjanidae e Balistidae foram as mais abundantes e frequentes, tendo sido assinalada a ocorrência de espécies raras para a costa brasileira, como Pristygenis alta (Gill, 1862) e Coryphaena equiselis Linnaeus, 1758. Primo et al. (2000) identificaram sete espécies de elasmobrânquios nos desembarques da pesca artesanal nas vilas de Poças e Siribinha: Rhizoprionodon lalandei (Valenciennes, 1841), Rhizoprionodon porosus (Poey, 1861), Rhinobatos horkeli (Muller \& Henle, 1841), Rhinobatos percellens (Walbaum, 1792), Sphyrna lewini (Griffith \& Smith, 1834), Dasyatis guttata (Bloch \& Schneider, 1801) e Dasyatis mariannae (Gomes, Rosa \& Gadig, 2000). Estas espécies são oriundas da pesca de linha de mão e secundariamente das redes de espera e espinhel, sendo a vila de Poças o ponto de desembarque mais produtivo em função dos saveiros possuírem maior autonomia e atuarem no mar e estuário, ao contrário dos barcos de madeira encontrados em Siribinha, que operam quase sempre no estuário. Segundo Primo et al. (2000), as capturas dos cações-viola (Rhinobatos spp.) são acidentais, constituindo-se como fauna acompanhante da pesca da lagosta e são categorizados como refugo, não apresentando nenhum interesse comercial, 
sendo comumente descartados em alto mar e, a depender da quantidade de gelo disponível, são trazidos à terra para uso na alimentação.
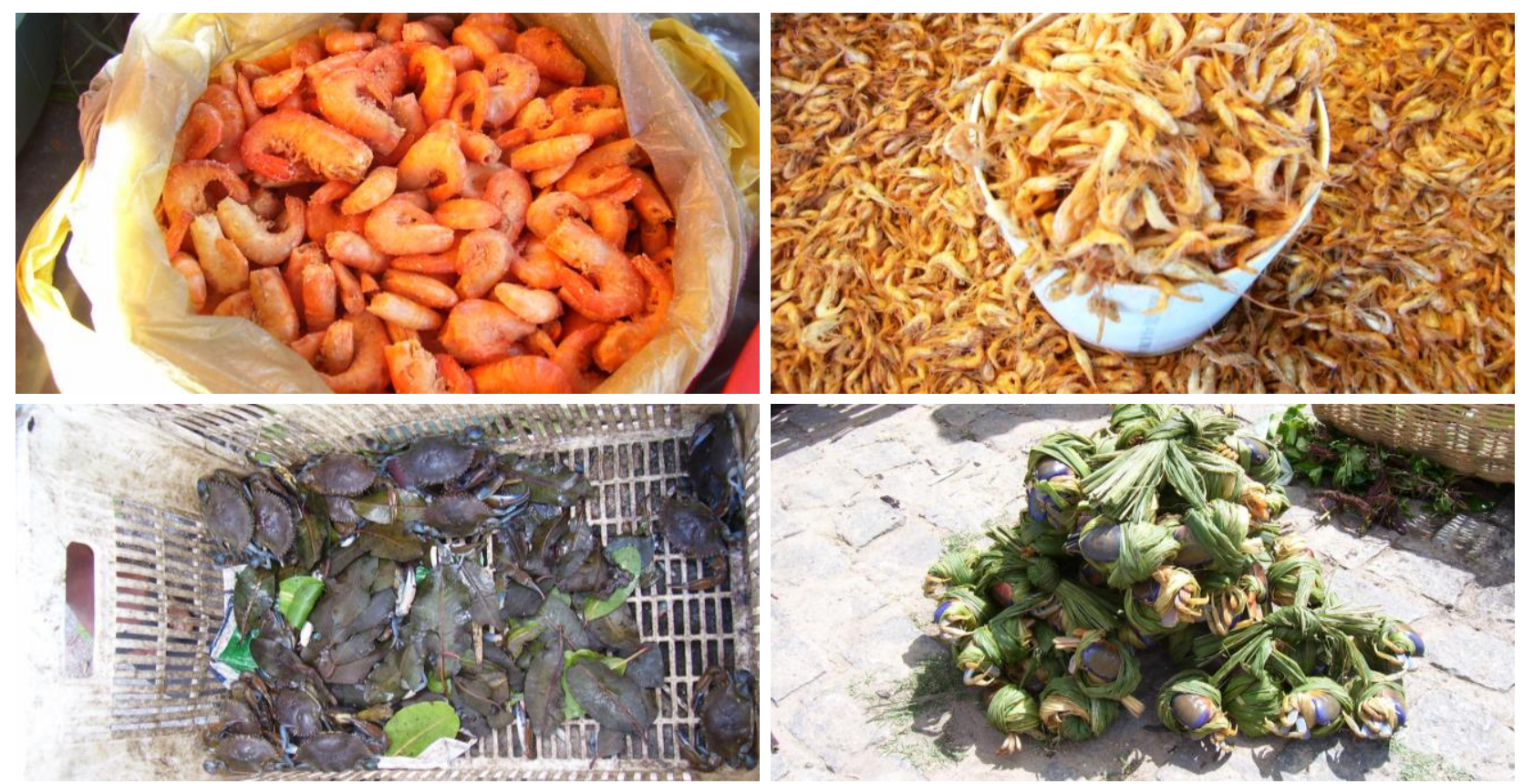

Figura 4. Recursos pesqueiros (crustáceos) comercializados na feira de Conde.

Em outro estudo, Santana e colaboradores (2003) registraram a ocorrência de espécies ameaçadas de extinção em listas oficiais nacionais e internacionais, como $R$. horkeli, Hippocampus reidi (Crisbur, 1933), Lutjanus analis (Cuvier, 1828) e Balistes vetula (Linnaeus, 1758). R. horkeli está nacionalmente em estado de sobrepesca com nível de conservação vulnerável, provavelmente, pelo seu alto grau de endemismo. Como estudos de biologia pesqueira são escassos na Bahia, estes dados indicam que medidas de controle e gerenciamento das artes de pesca e sobre os impactos da pesca artesanal devem ser adotadas em face à vulnerabilidade que se encontram oficialmente essas populações.

\section{Atividades de pesca artesanal no município de Conde}

Nas comunidades visitadas, as atividades de pesca sobressaem-se pelo fornecimento significativo de recursos pesqueiros, estando o segmento traduzido por duas atividades distintas: a pesca e a mariscagem (coleta de mariscos). Enquanto a pesca é exercida basicamente pelos homens que utilizam embarcações e apetrechos de pesca para captura de peixes e crustáceos, a mariscagem é uma atividade considerada feminina, embora alguns homens a exerçam, resultando na captura manual de moluscos e crustáceos ou utilizando armadilhas (COSTA-NETO, 2001). No ato de nominar tais atributos é perceptível uma forma de organização social que define relações e posições de gênero. Entretanto, há mulheres (esposas) que exercem a atividade da pesca, ajudando seus maridos.

A pesca artesanal caracteriza-se pelo trabalho familiar, onde todos são envolvidos na atividade e no beneficiamento do pescado, principalmente mariscos. O aratu, por exemplo, só é comercializado na condição de catado, uma vez que inexiste sua venda por unidade.

Em uma primeira análise, a pesca artesanal parece ser somente de subsistência, onde o pescador apenas consegue o básico para o sustento de sua família utilizando implementos rústicos, confeccionados com matéria-prima retirada da própria natureza nos ecossistemas adjacentes ao seu local de moradia. Os pescadores executam suas atividades individualmente ou em parceria, reunidos em duplas e equipes geralmente constituídas por parentes próximos, como irmãos. Ao compartilharem suas redes, os pescadores aumentam a eficiência de produção do pescado, que é dividido em partes iguais. $\mathrm{O}$ pescado pode ser comercializado imediatamente após sua captura ou ser congelado para vendagem posterior, ou, ainda, transformar-se em alimento para a subsistência dos moradores ou para o turismo.

Nas regiões estuarinas, que representam grande parte do litoral baiano, a mariscagem revestese de importância socioeconômica, absorvendo considerável mão-de-obra feminina, envolvendo, porém, na maioria das vezes, quase todos os membros da família no beneficiamento do produto (Fig. 
6). Segundo o Perfil do Setor Pesqueiro (BAHIA PESCA, 1994 apud BAHIA PESCA, 2003), esta categoria congregava 10.819 profissionais, que contribuem de forma decisiva na renda familiar, necessitando de especial atenção por parte dos órgãos governamentais, haja vista a peculiaridade da atividade.

As mulheres marisqueiras iniciam-se nesta atividade desde muito cedo, adquirindo o conhecimento sobre a arte de pesca seguindo suas mães ou parentes mais próximos às incursões nos locais de coleta. Os moluscos são capturados em diversos pontos ao longo do Rio Itapicuru, seus afluentes e lagoas que se formam após a cheia do rio. Os principais locais de coleta são as áreas localmente conhecidas como Imbé, Barra Nova, nas lagoas e nas margens do rio próximas às casas das marisqueiras e pescadores. Alguns destes lugares são distantes das residências: "O aruá a gente pesca [...]. É longe! Sabe onde é o Imbé? É uma hora de canoa remando" (Dona H., 39 anos).

O horário de ocorrência de maré vazante torna-se um dos fatores limitantes mais importantes para o exercício da atividade extrativista. O "maçunin" é capturado no período entre a vazante e a enchente da maré, visto que as marisqueiras precisam mergulhar ou usar um jereré para coletar o molusco. Quando mergulham, estas mulheres usam um tipo de peneira de aço para desenterrar os moluscos. Aquelas que não sabem nadar ou mergulhar usam o jereré para capturá-los. Todos os moluscos capturados são colocados nas embarcações, sem que haja escolha de tamanho.

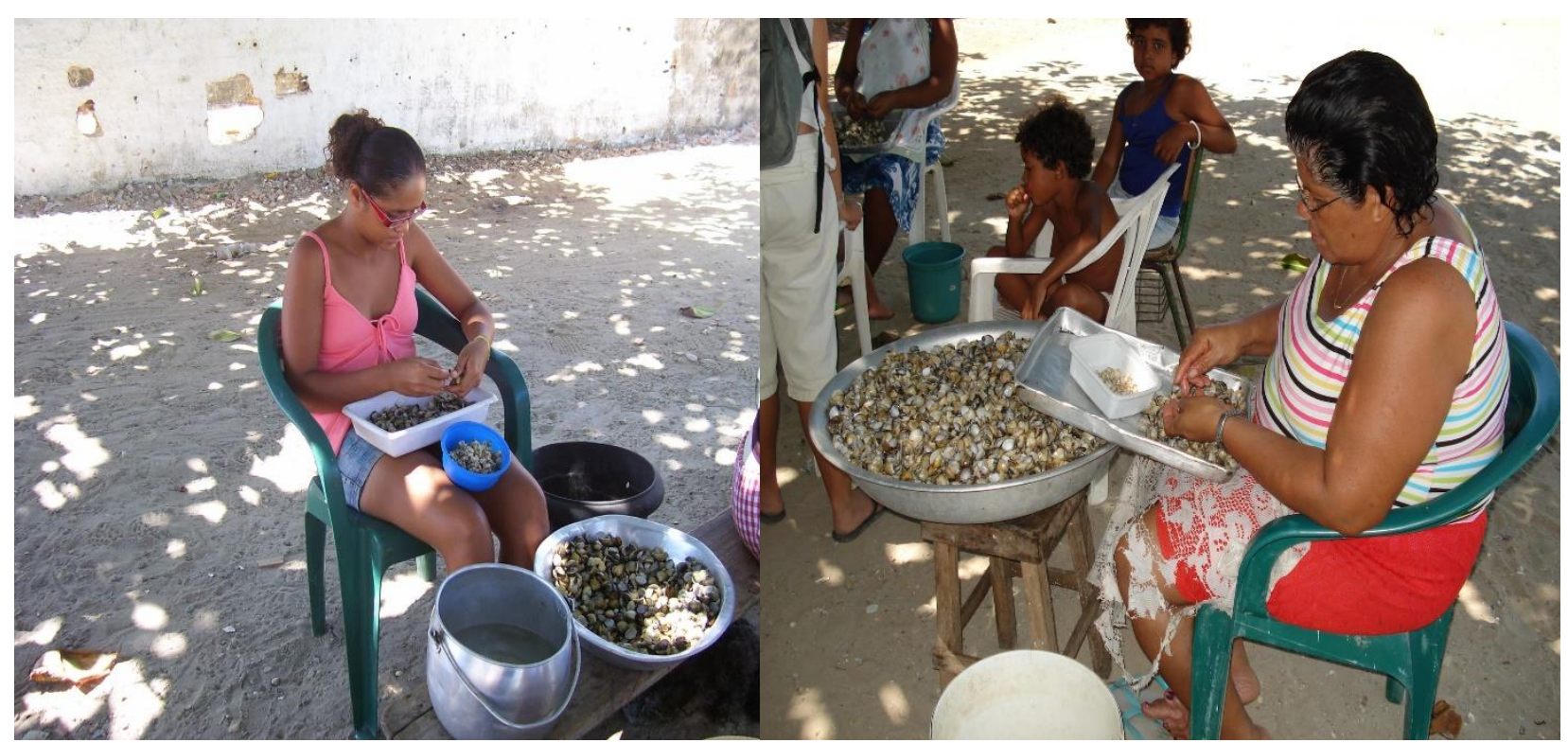

Figura 5. Beneficiamento familiar do maçunin. Comunidade de Siribinha.

Os locais de coleta de maçunin são próximos às casas das marisqueiras, mas como estes moluscos ficam enterrados distantes da beira do rio, requer a utilização de uma embarcação para o deslocamento até o local da captura. Estas embarcações retornam tão cheias de moluscos que as mulheres e crianças precisam voltar nadando para a margem. Ao retornarem da pescaria, as marisqueiras levam as bacias e baldes, repletos de maçunins, para suas casas. Algumas dessas marisqueiras chegam a se deslocar várias dezenas de metros do ponto de desembarque até suas residências com baldes sobre a cabeça. No caminho de casa elas vão coletando palha de coqueiro, que usarão como lenha para aferventar os moluscos.

Santana et al. (2003) afirmam que os pesqueiros explorados pela frota artesanal dos pescadores de Conde estão distribuídos sobre a região da plataforma continental e borda do talude, não ultrapassando 180 metros de profundidade em função da capacidade dos instrumentos de pesca. As artes de pesca são bastante diversificadas, variando desde rede de espera a linha de mão, sendo esta última a mais largamente utilizada (Tabela 1). Ocorre a caça submarina, mesmo sendo ilegal. Na maioria das comunidades, canoas e barcos a remo são as principais embarcações utilizadas, pois favorecem a navegação em locais rasos e por dentro dos canais do manguezal. Na categorização nativa, barco referese à embarcação que possui três bancos, enquanto canoa possui apenas dois ou mesmo nenhum. 
Tabela 1. Apetrechos de pesca observados durante o período de execução da pesquisa.

\begin{tabular}{|c|c|c|}
\hline Denominação & Sigla & Especificação \\
\hline Arrasto de praia & ARR & $\begin{array}{l}\text { Rede de arrasto tracionada com as mãos a partir da costa em enseadas e regiões de fundo } \\
\text { de lama. Usada com auxilio de embarcação a vela. }\end{array}$ \\
\hline Coleta manual & $\mathrm{COL}$ & Captura de marisco usando apenas as mãos. \\
\hline Covo camarão & CVC & $\begin{array}{l}\text { Armadilha de fundo semi-fixa, confeccionada com palheta rígida, com uma sanga (boca) } \\
\text { em uma das extremidades, apresentando formato cilíndrico. }\end{array}$ \\
\hline Covo peixe & $\mathrm{COP}$ & $\begin{array}{l}\text { Armadilha de fundo, cilíndrica, com estrutura de palheta, possuindo duas sangas em uma } \\
\text { das extremidades. }\end{array}$ \\
\hline Covo siri & CVS & $\begin{array}{l}\text { Armadilha de fundo semi-fixa, cilíndrica, confeccionada com palheta rígida, com uma } \\
\text { sanga (boca) em uma das extremidades. }\end{array}$ \\
\hline Curral & CUR & $\begin{array}{l}\text { Armadilha fixa, construída em geral por estaqueamento próximo a zona da maré, com o } \\
\text { propósito de conter os peixes no seu interior. Conhecida por camboa, tapagem ou curral. }\end{array}$ \\
\hline Cuvuco & CUV & Armadilha tipo covo, só que sem a sanga (fundo). \\
\hline Munzuá & MUZ & Armadilha de fundo, semi-fixa, feita de palheta, para captura de peixes. \\
\hline Tarrafa & TAR & $\begin{array}{l}\text { Rede que ao ser lançada sobre o cardume, se abre, forma um círculo e se fecha. Ao se } \\
\text { recolhida envolve os peixes. Sua utilização é feita em águas rasas, com ou sem apoio de } \\
\text { embarcações. }\end{array}$ \\
\hline Espinhel & ESP & $\begin{array}{l}\text { Consiste em uma linha principal de nylon torcido da qual partem linhas secundárias com } \\
\text { anzol em suas extremidades. A linha principal distende-se horizontalmente sobre a } \\
\text { lâmina d'água e a secundária, verticalmente. Vulgarmente conhecida como groseira, } \\
\text { espinhel. }\end{array}$ \\
\hline Ratoeira & RAT & Armadilha feita de lata de óleo ou de madeira para coleta de caranguejos \\
\hline Redinha & RED & Armadilha fixa feita de saco de estopa, colocada na entrada das tocas de caranguejos. \\
\hline Jereré & JER & $\begin{array}{l}\text { Rede em forma de saco raso, com abertura fixa (boca) de armação de madeira ou metal } \\
\text { (circular). É utilizado em águas rasas ou na borda de barcos. }\end{array}$ \\
\hline Linhas & LIN & $\begin{array}{l}\text { Resume todas as pescarias efetuadas com linhas, de fundo ou superfície, realizadas } \\
\text { manualmente. São conhecidas como linha de corso, linha de mão, linha de fundo, linha } \\
\text { de superfície etc. }\end{array}$ \\
\hline Linha / Espinhel & LES & Utilização na mesma pescaria de duas artes de pecas diferentes: linha e espinhel \\
\hline $\begin{array}{l}\text { Linha / Rede de } \\
\text { espera }\end{array}$ & LIR & Combinação de duas artes de pesca na mesma pescaria: linha e rede de espera \\
\hline
\end{tabular}

Os apetrechos de pesca mais utilizados pelos pescadores artesanais são: groseira ou espinhel, camboa ou curral, redes de espera, tarrafas, covo, jereré, linha de mão e ratueira. Além destes, o arrasto também é praticado, mas apenas durante a cheia do Rio Itapicuru. Outras artes de pesca conhecidas, porém não utilizadas na área, são o cuvucu e o munzuá. A utilização do primeiro foi registrada para pescadores de Sítio do Conde. O segundo parece com um covo, mas é maior e usado no mar ao invés de o sê-lo em água doce. Esses métodos de pesca estão adaptados às condições topográficas e hidrológicas específicas de cada um dos etnohabitats explorados, bem como às espécies que neles residem (Tabela 2).

A redinha tem sido considerada por alguns moradores/catadores como um problema ambiental porque além de aprisionar os caranguejos menores, sem muito valor comercial, estes acabam morrendo, assim como os indivíduos adultos que se emaranham nas redes deixadas, também poluem o ambiente: "Eu acho que é um atraso para a natureza. No tempo da andada os caranguejos ficam presos na redinha" (Seu F., 60 anos).

A tarrafa é um dos instrumentos pesqueiros mais difundidos e de maior número nas comunidades de pescadores artesanais do município de Conde. Este instrumento pesqueiro de origem portuguesa "propagou-se, no tempo pós-colombiano, com tal rapidez entre os indígenas brasileiros que hoje em dia, [...], parece um elemento cultural ameríndio, pois entrou até na mitologia indígena" (OTT, 1944). No passado, as tarrafas eram confeccionadas à base de fibras vegetais nativas, como o tucum (Arecaceae), mas desde que o nylon foi introduzido nas comunidades pesqueiras, passaram a ser feitas com este novo material.

A groseira é utilizada na captura de peixes de grandes dimensões, como cações, arraias e meros, mas também pega bagres e robalos. Trata-se de um apetrecho de origem portuguesa (OTT, 1944) que consiste em uma corda de nylon grossa na qual são amarrados, de forma espaçada, anzóis grandes (e. g., anzol 2.0, próprio para mero) geralmente iscados com peixes. A groseira apoia-se no fundo por meio de chumbadas colocadas em cordas de sustentação, que portam ainda boias em sua parte superior e são ligadas a ambas as extremidades da corda principal. Segundo os entrevistados, esta arte pesqueira era utilizada no "rio"/estuário quando era mais fundo e permitia a entrada de peixes maiores, como os cações. 
Tabela 2. Exemplos de recursos pesqueiros e as artes de pesca empregadas para sua captura.

\begin{tabular}{|c|c|c|c|c|c|c|c|c|c|c|c|c|}
\hline \multirow{2}{*}{$\begin{array}{l}\text { Tipo de } \\
\text { Pescado }\end{array}$} & \multicolumn{3}{|c|}{ Local } & \multicolumn{9}{|c|}{ Arte de pesca } \\
\hline & Rio* & Mar & Mangue & CVS & $\mathrm{CVC}$ & RED & RAT & JER & TAR & LIN & $\mathrm{COL}$ & LIR \\
\hline Siri-mangue & & & $\mathrm{X}$ & $\mathrm{X}$ & & & & $X$ & $\mathrm{X}$ & & & \\
\hline Siri-do-rio & $X$ & & $\mathrm{X}$ & $\mathrm{X}$ & & & & $X$ & $\mathrm{X}$ & & & \\
\hline Uçá & & & $\mathrm{X}$ & & & $X$ & & & & & X & \\
\hline Aratu & & & $\mathrm{X}$ & & & & & & & & $\mathrm{X}$ & \\
\hline Gaiamum & & & $\mathrm{X}$ & & & & $\mathrm{X}$ & & & & $\mathrm{X}$ & \\
\hline Camarão & $\mathrm{X}$ & $X$ & $\mathrm{X}$ & & $\mathrm{X}$ & & & $\mathrm{X}$ & & & & \\
\hline Cação** & & $\mathrm{X}$ & & & & & & & & $\mathrm{X}$ & & $X$ \\
\hline Corvina** & & $\mathrm{X}$ & & & & & & & $\mathrm{X}$ & $\mathrm{X}$ & & \\
\hline Robalo** & & $X$ & & & & & & & & $\mathrm{X}$ & & $X$ \\
\hline Badejo & & $X$ & & & & & & & & $X$ & & \\
\hline Cavala & & $X$ & & & & & & & & $\mathrm{X}$ & & \\
\hline Sororoca & & $X$ & & & & & & & $\mathrm{X}$ & $X$ & & \\
\hline Tainha & & $\mathrm{X}$ & & & & & & & $\mathrm{X}$ & & & $\mathrm{X}$ \\
\hline Xaréu ${ }^{* *}$ & & $X$ & & & & & & & & $\mathrm{X}$ & & \\
\hline Vermelho & & $\mathrm{X}$ & & & & & & & & $X$ & & $\mathrm{X}$ \\
\hline Baiacu & $X$ & $X$ & $\mathrm{X}$ & & & & & & $\mathrm{X}$ & & & $X$ \\
\hline Carapicum & $\mathrm{X}$ & & & & & & & & & & & $\mathrm{X}$ \\
\hline Bagre & $\mathrm{X}$ & $\mathrm{X}$ & $\mathrm{X}$ & & & & & & $\mathrm{X}$ & & & $X$ \\
\hline Carapeba & $\mathrm{X}$ & & & & & & & & & & & $\mathrm{X}$ \\
\hline Caranha** & & $\mathrm{X}$ & & & & & & & & $\mathrm{X}$ & & \\
\hline
\end{tabular}

*Aqui significa estuário.; ${ }^{* *}$ Linha de mão.

Vale salientar que a introdução de produtos sintéticos (ex. nylon, isopor, plásticos) nos apetrechos de pesca (redes, boias, caixas, telas etc.) e a inserção de motores nas embarcações causaram grandes transformações para a pesca artesanal (SANTOS, 2012). O surgimento das fibras sintéticas aumentou significativamente o tempo de vida das artes de pesca e lhes conferiu maior resistência. A mecanização da produção de fios, redes e cabos permitiu a construção de artes de pesca cada vez maiores e mais complexas (OTT, 1947).

O covo é um instrumento que tem o formato de uma caixa retangular contendo uma abertura e uma porta, o qual é colocado em águas rasas, principalmente em lagoas e áreas de brejo. Geralmente, isca-se com coco assado, crustáceos, peixes e insetos para a captura, por exemplo, de camarões, bagres, traíras e caboges, respectivamente. Após algum tempo de armado, o pescador vai desmariscá-lo: retira o pescado; limpa a armadilha; repõe a isca e recoloca o covo, voltando depois para vigiá-lo novamente.

A camboa pode ser pensada como uma das formas pelas quais certas áreas do mangue são temporariamente possuídas pelos pescadores, que detêm para si os recursos pesqueiros que ficam presos em seu interior. Trata-se de uma armadilha móvel construída a partir das palhas de piaçava (Attalea funifera), as quais, transformadas em esteiras, são unidas umas às outras para formar um cercado visando ao aprisionamento do pescado. De camboa, pescam-se tainhas, robalos, carapebas, meros, bagres, caramurus, aramaçás, niquins, mututucas, siris etc. Segundo um pescador-camboeiro, a tainha é o peixe "efetivo" de camboa. O peixe entra e na medida em que a maré vai secando ele nada na direção do "chiqueiro", uma única esteira de forma circular colocada no final do cercado, armada propositadamente em um nível mais baixo para que os peixes agrupem-se na poça d'água, facilitando a captura. Pescadores do sul do Estado também utilizam camboa (RÊGO, 1994).

As redes de espera são confeccionadas segundo malhagem e número de nylon apropriados à captura de certas espécies e possuem muitas braças de comprimento (braça é uma medida comumente usada pelos pescadores equivalente ao comprimento de dedo a dedo de um homem de braços abertos, segundo Rêgo [1994]). A "carapebeira", por exemplo, rede feita com nylon 40 e malha 14, é específica para carapebas e afins (Gerreidae). O "caçueiro", por sua vez, é uma rede mais resistente própria para robalão (Centropomus undecimalis Bloch, 1792) e outros peixes maiores. As redes ficam suspensas na coluna d'água com a parte inferior tocando o assoalho marinho devido à presença de chumbadas e a parte superior boiando, graças a boias de isopor. Elas são armadas com uma distância mínima de 100 
metros umas das outras para permitir que os peixes circulem entre os "pesqueiros". Quando armadas no estuário, elas são seguras por varas de madeira chamadas de "calão", feitas a partir do caule do manguevermelho (Rizophora mangle L.). No sul do Estado da Bahia, calão refere-se a uma rede de arrasto utilizada para a captura de peixes e camarão, confeccionada com nylon 16 e manejada por um grupo de pescadores na praia e por outro grupo em uma canoa (RÊGO, 1994).

A grande maioria dos pescadores confecciona suas próprias redes e tarrafas, mas eles têm dificuldade para conseguir material devido especialmente ao preço do mesmo, uma vez que um carretel de $250 \mathrm{~m}$ de linha 0.40 custa $\mathrm{R} \$ 23,00$; são usados dois carretéis para se fazer uma rede de $100 \mathrm{~m}$.

$\mathrm{Na}$ vigia das redes, cada dupla sai duas vezes ao dia: a primeira vigia ocorre no amanhecer, entre às 05:00h e às 06:00h; a segunda acontece no entardecer, entre às 16:00h e às 17:00h. A permanência no mar para a vigia das redes dura em média uma hora. $\mathrm{O}$ ato de vigiar consiste em suspender as redes e desmariscar o pescado, retornando com as redes caso estas apresentem grandes estragos ocasionados por peixes, como robalos e baiacus, tartarugas ou mesmo barcos a motor de outras comunidades. Finda a vigia, os pescadores, ao retornarem, armam velas para aproveitar o vento. Com cerca de 200 metros de distância da praia, eles baixam as velas e começam a remar. A simplicidade da tecnologia pesqueira e o pequeno tamanho das redes permitem uma pescaria bastante móvel, permitindo também que as redes sejam colocadas, checadas, limpas, recolocadas ou removidas mais rapidamente. Segundo Berkes (1971), estas adaptações resultam em um sofisticado sistema de exploração dos recursos no qual um profundo conhecimento do ambiente e cooperação na coleta dos animais são altamente importantes.

De acordo com os indivíduos entrevistados, a lontra (Lutra longicaudis Olfers, 1818) e o "guaxele" (Procyon cancrivorus Cuvier, 1865) são os dois animais que mais atrapalham a atividade de pesca, pois competem com os pescadores pelo pescado e destroem as armadilhas de pesca. Além destes dois mamíferos, os pescadores apontaram a traíra e o paru como predadores naturais dos camarões, atrapalhando a pesca dos mesmos. Quando entram no covo, comem toda a produção. Ainda, o aruá também cai na armadilha (covo) e os exemplares maiores acabam impedindo a entrada dos camarões.

Os pescadores e marisqueiras entrevistados afirmavam sempre que não há lugares específicos para a atividade de pesca, coleta de caranguejos e mariscagem, uma vez que todos executam suas tarefas em qualquer lugar (exceto dentro de propriedades particulares, como fazendas e sítios, quando os donos proíbem o acesso). Foi dito que os moradores de qualquer comunidade têm livre acesso aos locais de pesca. No entanto, a observação comportamental e os próprios depoimentos de alguns pescadores demonstram que existem certos locais, como os "pesqueiros"/recifes artificiais e áreas de pesca mantidas em segredo, que são de uso exclusivo daqueles que detêm a posse sobre o pesqueiro ou que guardam segredo a respeito dos locais mais piscosos. Além de aparentemente não serem nomeados, os pesqueiros não são localmente assumidos como possuindo donos, embora o que se observa na prática é que estas unidades microambientais (CORDELL, 1983, 1985, 1989) constituem espaços territorializados, ostensivamente marcados e respeitados pelos demais integrantes do grupo local. Por exemplo, na comunidade de Sempre Viva foi registrada a informação de que os membros que fazem parte da Associação de Pescadores têm preferência na colocação das camboas. Ainda, o lugar no qual uma rede de espera foi colocada é marcado com boias de isopor ou outras marcas. Tais locais, contudo, não têm caráter de posse permanente; assim, quando um pescador-redeiro remove sua rede, outro pode armar a sua própria rede no mesmo lugar anteriormente ocupado. No entanto, às vezes, estes espaços são invadidos, gerando-se conflitos internos.

Um caso muito particular ocorre na comunidade de Ilha das Ostras, uma vez que os territórios de pesca nas áreas alagadas do Rio Crumaí, denominados de regos, são privados e transmitidos de pai para filho há mais de um século. Cada família possui locais, "braços", no rio Crumaí que são abertos e utilizados para a pesca. Cada rego tem uma denominação, como, por exemplo, rego do Zé Rosa, do Porto Velho e Riacho da Vargem, e apenas o dono é quem pode exercer a atividade de pesca. Nesta localidade, o principal recurso extraído é o camarão.

$\mathrm{O}$ uso comunal e segredado das águas entre os pescadores artesanais deve ser compreendido como uma das formas de gestão comunitária dos recursos pesqueiros (DIEGUES, 1997). Na visão de Ramalho (2008):

"A utilização comunal do espaço aquático, através do uso dos pesqueiros, pode ser compreendido como aquele que é estabelecido e aceito de modo coletivo por vários pescadores de determinada localidade e que é parte integrante de suas tradições de trabalho e 
sociabilidade, possuindo lógicas de ordenamento, condutas aceitas de utilização das águas e, portanto, regras a respeitar-se de inclusão e exclusão comunitária. Tudo isso fundado no primado da apropriação não privada das águas".

A prática do segredo foi analisada por Forman (1967) como um "mecanismo ecologicamente adaptativo [...] que minimiza a competição e previne a sobrepesca". Acheson (1981) cita vários autores que observaram exemplos onde os locais de pesca não são formalmente possuídos, mas onde o segredo e o manejo de informação operam para efetuar alguns direitos de propriedade sobre os recursos. Assim, para evitar a competição e garantir o sucesso na pescaria, os pescadores utilizam o artifício do "segredo de pesca", que resulta na localização e utilização de locais de pesca que, parafraseando Posey (1983), poderiam constituir-se "ilhas de recursos" dentro do estuário, às quais, são mantidas em segredo por um dado pescador, permitindo a este o acesso aos recursos de forma continuada.

No entanto, a pesca industrial, a expansão da atividade turística e da especulação imobiliária, a poluição industrial e doméstica, a criação de complexos portuários e de fazendas para cultivo de camarão etc. resultaram na expropriação intensiva de muitos territórios de uso comum (DIEGUES, 1997).

\section{Problemas e Soluções}

Durante uma reunião ampliada realizada com moradores das comunidades de Cobó, Sempre Viva e Ilha das Ostras, eles próprios levantaram alguns problemas socioambientais e sugeriram soluções (Tabela 3). Segundo a opinião dos pescadores do Cobó, o principal conflito existente é a restrição de veículos até a margem do porto do Rio do Góes, uma vez que o acesso - a estrada de chão - está proibido por ordem de um proprietário de terras (um fazendeiro). Observa-se uma porteira com cadeado que impede a aproximação de carros motorizados ou mesmo animais de tração. Com isso, os pescadores e marisqueiras têm de andar quase um quilômetro para chegar ao porto, levando consigo todos os apetrechos, inclusive os barcos a remo. Eles reclamam que esta estrada era usada por eles há gerações, mas que agora o acesso está proibido por um agente externo à comunidade.

Já os moradores da comunidade de Ilha das Ostras denunciam que as matas paludosas estão sendo desmatadas e os brejos estão secando. De fato, o desmatamento compromete as áreas alagadas, quando fazendeiros desmatam para aumentar áreas de pasto para criação de búfalo. Os entrevistados também disseram que as áreas de drenagem ("levadas") abertas pelos proprietários de terra fazem com que a água escoe mais facilmente, tornando as áreas alagadas mais rasas. Com isto, a vegetação cresce e atrapalha a circulação dos pescadores. Segundo os moradores, as "levadas" que são abertas pelos fazendeiros podem chegar até o Rio Itapicuru.

Outro problema apontado pelos pescadores de Ilha das Ostras foi a existência de tanques de criação de peixes próximos do Rio Crumaí. Eles disseram que peixes exógenos à fauna ictiológica local foram introduzidos no sistema, a pirarara e o caboje-paraguai, os quais foram observados na região. $\mathrm{O}$ primeiro é um predador: "Acaba com os outros peixes". O caboje conhecido como paraguai é, segundo os entrevistados, "mais forte, mais troncudo e mais claro que o caboje-comum". Na percepção local, a tilápia também apareceu na região, mas está sumida ultimamente.

Dentre as dificuldades vivenciadas pelos pescadores e marisqueiras, foi citada a pouca quantidade de material (armadilhas de pesca) para a captura dos recursos: "Se não tiver armadilha, não tem pesca [...]" (Dona M., marisqueira de Sítio do Conde). Neste caso, os entrevistados falaram sobre a dificuldade de obterem matérias-primas vegetais para confecção de seus apetrechos de pesca, especialmente quando as espécies botânicas fornecedoras de recursos estão localizadas dentro de propriedades particulares e os donos não permitem a sua retirada.

Como Marques (1995) observa, desconexões vivenciadas privam o pescador não só de recursos que são essenciais à sua reprodução cultural, mas que também o são à sua sobrevivência e continuidade biológicas. Segundo o autor, configura-se um descompromisso sincrônico com as gerações presentes e diacrônico, com as gerações futuras. Nestas condições, a transição para um desenvolvimento sustentável constitui-se simplesmente em uma impossibilidade (SACHS, 1992). Uma das formas de garantir o desenvolvimento sustentável das comunidades locais seria a realização de um reflorestamento com as espécies de importância cultural, permitindo uma fonte segura de matéria-prima necessária à pesca artesanal, à conservação das espécies e da cultura local. 
Tabela 3. Lista de problemas e soluções sócio-ambientais apontados por moradores de três comunidades do município de Conde, Bahia.

\begin{tabular}{ll}
\hline Problemas & Soluções \\
\hline Uso de redinhas para coletar caranguejos & O pescador não deve deixar a redeinha no manguezal. \\
& Fiscalização. \\
Desmatamento do manguezal & Reflorestamento. \\
& Horto comunitário (papel das escolas locais na educação dos jovens e \\
& adultos). \\
Seca & Fiscalização contra o desmatamento. \\
Falta de saneamento básico (fossa) & Prefeitura do Conde. \\
Privatização de áreas turísticas & O dinheiro cobrado deve ser usado para fazer a limpeza da área recreativa. \\
(p.ex., Cavalo Russo) & Regularização de uso. \\
& Turismo sustentado. \\
& Contratar mão-de-obra local. \\
Privatização de áreas por grandes & Regularização. \\
empresários & A coleta deveria ocorrer três vezes/semana. \\
Lixo (a coleta é feita uma vez por semana) & Saneamento básico. \\
Doenças (esquistossomose) & Fazer seleção dos indivíduos coletados e não pegar as fêmeas. \\
Mortandade do caranguejo-uçá & Respeitar o período de defeso. \\
& Chamar a fiscalização. \\
Baixo número de embarcaçães & As associações de pescadores devem separar uma porcentagem do que é \\
& arrecadado para compra de madeira e/ou ferramentas. \\
Desperdício da safra de frutas & Criar associação. \\
& Beneficiamento de polpas. \\
Plantio de eucalipto & Impedir a expansão do cultivo. \\
Criação de animais (porcos criados às & Fiscalização. \\
margens do rio) &
\end{tabular}

Quase todos os pescadores e marisqueiras entrevistados reivindicaram melhorias para as condições da pesca. Eles têm real necessidade de um beneficiamento mais eficiente para os recursos pesqueiros, incluindo transporte, armazenamento e comércio. Na fala de uma marisqueira: "Aí sim, né? Um lugar onde a gente guardasse o que a gente não vendesse, né?”. (Dona A., 67 anos). Entre os pescadores artesanais, o que se verifica é a utilização de equipamentos rudimentares, a apropriação da produção por intermediários e, acima de tudo, o desinteresse do Estado em incrementar a atividade pesqueira por meio de recursos financeiros e materiais, o que aumentaria em boa medida a produtividade (SANTOS, 1991).

Esta rápida incursão nos problemas socioambientais vivenciados pelas comunidades pesqueiras do município de Conde, Litoral Norte do Estado da Bahia, revela o quanto complexo é o fenômeno e, por isso mesmo, torna-se necessário desenvolver estudos interdisciplinares que promovam não apenas a sistematização dos conhecimentos tradicionais, aliados aos técnico-científicos, mas que busquem garantir a sustentabilidade cultural e ambiental da região.

\section{REFLEXÃO FINAL}

A atividade turística, da forma como vem sendo implementada no Litoral Norte do Estado da Bahia, não tem oferecido uma opção viável para a reprodução econômica sustentável das populações que vivem na região. O que se verifica é uma enorme pressão sobre o preço das terras, provocada pelo fim de um longo período de estagnação econômica, ao lado da extinção de uma forma de ocupação territorial baseada no arrendamento ou na meia, que garantia a fixação das famílias nos povoados rurais, geralmente localizados a oeste da rodovia que corta a região. Consequências previstas em outros estudos realizados na região podem hoje ser atestadas, como é o caso do inchaço e do afavelamento das povoações onde a terra ainda está acessível. As ofertas de trabalho e emprego não atingem significativamente as parcelas mais pobres da população, desqualificadas para atender a um público exigente com relação aos serviços oferecidos. O trabalho ocasional não oferece garantias maiores e a informalidade continua predominante em toda área.

As recentes transformações socioeconômicas no Litoral Norte vêm modificando sobremaneira as relações produtivas locais, baseadas na interação direta com a natureza, no acesso à ampla disponibilidade dos recursos naturais e em formas de uso do território que até recentemente eram regulados por normas sociais estabelecidas pelos agrupamentos humanos locais. Dotadas de um arcabouço conceitual e práticas tradicionais de grande valor para a conservação desses ecossistemas, 
essas comunidades litorâneas estão perdendo espaço para grandes empreendimentos turísticos, que introduzem novos valores sociais, novas formas de trabalho e de relacionamento com os espaços antes reservados à agricultura, ao extrativismo, à pesca e à mariscagem. Além dos altos investimentos do setor hoteleiro que vêm se expandindo em direção ao extremo norte no Litoral Norte, a carcinicultura e a pesca industrial predatória ameaçam, sobretudo, a pesca artesanal. A concorrência advinda dessas atividades e a sobre-exploração de certas espécies, associadas ao baixo poder de organização de pescadores/marisqueiras e à falta de planejamento de suas atividades, caracterizam um cenário de intensa preocupação para ambientalistas, cientistas e pela população que ressente o desaparecimento e a escassez de determinadas espécies, bem como se vê isolada e sem mecanismos de interlocução e negociação com representações do poder local ou estadual.

Considerando-se, pois, a atividade turística como ação desenvolvimentista delineada para o Litoral Norte da Bahia, sua sustentabilidade apenas poderá ser alcançada por meio da participação das comunidades nativas, uma vez que elas conhecem as características ecológicas do meio natural e o seu limite de saturação (MENDONÇA, 1996). A política de desenvolvimento planejada para a região Litoral Norte do Estado da Bahia deveria incluir as tradições culturais das populações mediante as necessidades endógenas no contexto dos recursos locais. Governo e entidades privadas poderiam ainda buscar a melhoria das condições de vida da população local pela sustentabilidade cultural, procurando incentivar o desenvolvimento das atividades culturais e artesanais. Isso possibilitaria aos sujeitos não só o aumento de sua renda, mas a recuperação das atividades artesanais e a promoção da cultura local, valorizando o patrimônio biocultural. Os pescadores, em particular, também poderiam ser engajados no processo de desenvolvimento como guias ecológicos treinados para levar grupos de turistas através de trilhas no estuário por eles conhecidas e utilizadas. O manejo correto do espaço e dos recursos naturais e o respeito pelo conhecimento tradicional permitiriam a manutenção da qualidade do meio ambiente, assim como a conservação dos recursos para usufruto tanto das gerações presentes quanto futuras (SACHS, 1995).

No entanto, a pesca industrial, o desenvolvimento da carcinocultura, os empreendimentos turísticos e a especulação imobiliária vêm excluindo cada vez mais os pescadores do livre acesso ao mar e dos recursos pesqueiros, por meio da restrição de caminhos utilizados há mais de um século, na comunicação das povoações situadas mais ao interior do continente com o mar, além da apropriação das praias, o que impede a descarga do pescado e atracagem das embarcações. Soma-se a estes aspectos, a falta de políticas públicas voltadas para a consolidação dos modos artesanais de pesca e que assegurem uma cadeia produtiva do pescado que viabilize a permanência das comunidades pesqueiras ao longo do litoral.

É fato que inúmeros são os casos de exclusão e perda de identidade cultural de comunidades tradicionais registrados no litoral brasileiro e inúmeras experiências de resgate e superação destas perdas já foram e estão sendo desenvolvidas por instituições governamentais e não-governamentais. Estas experiências no Brasil, em sua maior parte, têm como foco final a constituição de áreas de conservação destinadas ao uso sustentável dos recursos naturais por estas comunidades, a exemplo de Reservas Extrativistas (RESEX) e Reservas de Desenvolvimento Sustentável (RDS) (BRASIL, 2007). As primeiras têm recebido atenção por se tratarem de uma categoria de unidade de conservação que une preocupações ambientalistas com as prerrogativas das comunidades extrativistas tradicionais (CHAMY, 2006). No âmbito dos pescadores artesanais, a defesa dos territórios tradicionais de pesca não é tarefa fácil, uma vez que resulta da difícil definição da apropriação dos espaços marinhos, ambiente fora do contexto social dos envolvidos (CORDELL, 1983, 1985, 2001).

O Programa de Desenvolvimento Sustentável para a APA do Litoral Norte descreveu as características socioambientais das comunidades pesqueiras, as formas de artes de pesca artesanal utilizadas por elas e a caracterização dos recursos pesqueiros extraídos na região (BAHIA, 2001). A partir deste conhecimento, o estudo indicou como prioridade a criação da RESEX como forma de garantir a manutenção das comunidades tradicionais e sua sustentabilidade, garantindo a inclusão das populações em projetos sustentáveis de geração de renda na APA Litoral Norte.

Atualmente, as requisições para a formação de Reservas Extrativistas Marinhas (REMs) têm sido inúmeras, o que pode pressupor um fortalecimento da emancipação política destas comunidades litorâneas ou uma intervenção induzida por instituições governamentais e não-governamentais. De acordo com o artigo 18 do Sistema Nacional de Unidades de Conservação da Natureza (lei n. 9985 de 18/06/2000), uma Reserva Extrativista Marinha é definida como: 


\begin{abstract}
"Área utilizada por populações extrativistas tradicionais, cuja subsistência baseia-se no extrativismo e, complementarmente, na agricultura de subsistência e na criação de animais de pequeno porte, e tem como objetivos básicos proteger os meios de vida e a cultura dessas populações, e assegurar o uso sustentável dos recursos naturais da unidade".
\end{abstract}

No Estado da Bahia, existem duas REMs institucionalizadas: a de Iguape, localizada em Maragojipe e Cachoeira, na região da Baía de Todos os Santos, criada em agosto de 2000, e a de Corumbau, localizada em Prado, litoral sul do Estado, criada em setembro de 2000. Com o processo de formação iniciado por meio de abaixo-assinados entre os próprios pescadores, após a criação das poligonais, estas reservas extrativistas passaram por um processo de desenvolvimento da articulação comunitária e do conhecimento de seu estoque pesqueiro e manejo tradicional para dar prosseguimento à elaboração dos respectivos planos de manejo.

Ainda que a criação da Reserva Extrativista Flúvio-Marinha do município de Conde seja uma possibilidade futura, o presente estudo teve como objetivo principal possibilitar às comunidades pesqueiras do estuário do Rio Itapicuru e região costeira adjacente a possibilidade de empoderamento e apropriação de seus conhecimentos tradicionais de modo a estabelecer uma perspectiva futura de sua perpetuação e da conservação da biodiversidade no Litoral Norte do Estado da Bahia. De acordo com Diegues (2004), reconhecer a importância do conhecimento tradicional na gestão dos recursos naturais é de fundamental importância para a manutenção da conservação da biodiversidade.

\title{
AGRADECIMENTOS
}

A Sidrônio Bastos, Diretor de Projetos Ambientais (DIPRO) do Instituto de Meio Ambiente e Recursos Hídricos (INEMA) do Estado da Bahia, pelo apoio financeiro ao projeto (convênio $\mathrm{N}^{\circ}$ 003/2007); á Erika Campos, ex-Coordenadora de Projetos Socioambientais do INEMA, pelo contato inicial e convite para retornar a trabalhar com os pescadores do município de Conde; ao professor Washington Rocha, ex-Coordenador da Assessoria Especial de Relações Internacionais da Universidade Estadual de Feira de Santana, pelo desenvolvimento do convênio $N^{\circ}$ 003/2007. Agradecemos aos biólogos Dídac Santos Fita e Lílian Mascarenhas pela colaboração nas atividades técnico-científicas do Dia do Meio Ambiente nas Comunidades do Município de Conde, promovido pela Associação Comunitária para Desenvolvimento dos Pequenos Produtores Rurais do Cobó, no dia 16 de março de 2008.

Agradecimentos especiais a todos os entrevistados que contribuíram com preciosas informações sobre o conhecimento ecológico tradicional na área de estudo, pois sem eles grande parte do trabalho não existiria. Especialmente aos pescadores e marisqueiras pelas coletas de peixes e mariscos, assim como material botânico utilizado como recurso pesqueiro local. Agradecemos também aos representantes de cada associação de pescadores das comunidades estudadas, pelo apoio e incentivo à nossa pesquisa.

\section{REFERÊNCIAS}

ACHESON, J.M. 1981. Anthropology of fishing. Annual Review of Anthropology, v. 10, p. 275-316, 1981.

ALVES, R.R.N.; NISHIDA, A.K. Aspectos socioeconômicos e percepção ambiental dos catadores de caranguejo-uçá Ucides cordatus cordatus (L., 1763) (Decapoda, Brachyura) do estuário do Rio Mamanguape, nordeste do Brasil. Interciencia, v. 28, n. 1, p. 1-8, 2003.

BAHIA. PRODESU - Programa de Desenvolvimento Sustentável para a Área de Proteção Ambiental do Litoral Norte da Bahia: relatório síntese. Salvador: SEPLANTEC, 2001.

BAHIA PESCA. Boletim estatístico da pesca marítima e estuarina. Ano 2002. Salvador: Governo do Estado da Bahia, Secretaria de Agricultura, Irrigação e Reforma Agrária/Bahia Pesca, 2003.

BAQUEIRO, F.; CARVALHO, A.C.; ROCHA, A.C. Litoral Norte da Bahia, formação territorial e dinâmica das relações históricas de ocupação. In: Projeto Costa dos Coqueiros. Salvador: Instituto de Hospitalidade, 1998.

BARRERA-BASSOLS, N.; TOLEDO, V.M. Ethnoecology of the Yucatec Maya: symbolism, knowledge and management of natural resources. Journal of Latin American Geography, v. 4, n. 1, p. 9-41, 2005.

BAYLEY, P.B.; PETRERE-JÚNIOR, M. Amazon fisheries: assessment methods, current status and management options. Can. Spec. Publ. Fish. Aquat. Sci., n. 106, p. 385-398, 1989.

BERGAMASCO, S.M.P.P.; ANTUNIASSI, M.H.R. Ecodesenvolvimento e agricultura: comentando o pensamento de Ignacy Sachs. In: VIEIRA, P.F.; RIBEIRO, M.A.; FRANCO, R.M.; CORDEIRO, R.C. (orgs.). 
Desenvolvimento e meio ambiente no Brasil: a contribuição de Ignacy Sachs. Porto Alegre: Pallotti; Florianópolis, APED, 1998. p. 273-284.

BERKES, F. Fishery resource use in a Subarctic Indian community. Human Ecology, v, 5, n. 4, p. 289-307, 1971.

BLANDIN, P.; LAMOTTE, M. Recherche d'une entité écologique correspondant à l'étude des paysages: la notion d'écocomplexe. Bull. Ecol., v. 19, n. 4, p. 547-555, 1988.

BRASIL. Sistema Nacional de Unidades de Conservação. Disponível em <www.mma.gov.br/port/sbf/dap/doc/snuc.pdf>. Acesso em: 14 mar 2007.

CARQUEIJA, C. Declínio das populações do caranguejo-uçá no Nordeste. In: ENCONTRO DE ZOOLOGIA DO NORDESTE, 15. Resumos... Salvador: Ed. UNEB, 2005. p. 99-101.

CASTRO, F. Aspectos ecológicos da pesca no Rio Grande, próximo às cidades de Icém (SP) e Fronteira (MG). In: ENCONTRO DE CIÊNCIAS SOCIAIS E O MAR NO BRASIL, 2. Coletânea de trabalhos apresentados... São Paulo: IOUSP/F. FORD/UICN, 1988. p. 170-179.

CENTRO DE ESTATÍSTICAS E INFORMAÇÃO. Informações básicas dos municípios baianos: região litoral norte. Salvador: Governo do Estado da Bahia, 1994.

CHAMY, P. Reservas extrativistas marinhas: um estudo sobre posse tradicional e sustentabilidade. Disponível em <www.anppas.org.br/encontro_anual/encontro1/gt/conhecimento_local/Paula\%20Chamy.pdf>. Acesso em: 22 abr. 2006

CORDELL, J. Locally managed sea territories in Brazilian coastal fishing. Roma: FAO, 1983.

CORDELL, J. Sea tenure in Bahia. Washington, D.C.: National Research Council, 1985.

CORDELL, J. Social marginality and sea tenure in Bahia. In: A sea of small boats. Cambridge: Cultural Survival Inc., 1989. p. 125-151.

CORDELL, J. Marginalidade social e apropriação territorial marítima na Bahia. In: DIEGUES, A.C.; MOREIRA, A.C. (orgs). Espaço e recursos naturais de uso comum. São Paulo: NUPAUB/USP, 2001. p. 139159.

COSTA-NETO, E.M. A cultura pesqueira do litoral norte da Bahia: etnoictiologia, desenvolvimento e sustentabilidade. Salvador: EDUFBA; Maceió: EDUFAL, 2001.

DIEGUES, A.C.S. Diversidade biológica e culturas tradicionais litorâneas: o caso das comunidades caiçaras. São Paulo: NUPAUB-USP, 1988.

DIEGUES, A.C.S. Repensando e recriando as formas de apropriação comum dos espaços e recursos naturais. In: VIEIRA, P.F.; WEBER, J. (orgs.). Gestão de recursos naturais renováveis e desenvolvimento: novos desafios para a pesquisa ambiental. São Paulo: Cortez, 1997. p. 407-432.

DIEGUES, A.C.S. Human populations and coastal wetlands: conservation and management in Brazil. Ocean \& Coastal Management, v. 42, p. 187-210, 1999.

DIEGUES, A.C.S. Povos e águas: inventários de áreas úmidas. 2. ed. São Paulo: NUPAUB, 2002.

DIEGUES, A.C.S. Conhecimento tradicional e apropriação social do ambiente marinho. In: RODRIGUES, E.; PAULA, A.C.; ARAUJO, C.M. (orgs.). Roteiros metodológicos: plano de manejo de uso múltiplo das Reservas Extrativistas Federais. Brasília: IBAMA, 2004. p. 125-157.

DIAS, T.; ROSA, R. Recursos pesqueiros explorados pelos pescadores artesanais no manguezal da Reserva Ponta do Tubarão (Macau-Guamaré/RN). In: ENCONTRO DE ZOOLOGIA DO NORDESTE, 15 . Resumos... Salvador: Ed. UNEB, 2005. p. 458.

DORIA, C.R.C.; ARAÚJO, T.R.; SOUZA, S.T.B.; TORRENTE-VILARA， G. Contribuição da etnoictiologia à análise da legislação pesqueira referente ao defeso de espécies de peixes de interesse comercial no oeste da Amazônia Brasileira, rio Guaporé, Rondônia, Brasil. Biotemas, v. 21, n. 2, p. 119-132, 2008.

FIGUEIREDO, S.L. Turismo e cultura: um estudo das modificações culturais no município de Soure em decorrência da exploração do turismo ecológico. In: LEMOS, A.I.G. (org.). Turismo, impactos socioambientais. São Paulo, HUCITEC, 1996. p. 201-222.

FISCARELLI, A.G.; PINHEIRO, M.A.A. Perfil sócio-econômico e conhecimento etnobiológico do catador de caranguejo-uçá, Ucides cordatus (Linnaeus, 1763), nos manguezais de Iguape (24 41'S), SP, Brasil. Actualidades Biológicas, v. 24, n. 77, p. 129-142, 2002.

FLEURY, L C.; ALMEIDA, J. Populações tradicionais e conservação ambiental: uma contribuição da teoria social. Revista Brasileira de Agroecologia, v. 2, n. 3, p. 3-19, 2007.

FORMAN, S. Cognition and the catch: the location of fishing spots in a Brazilian coastal village. Ethnology, v. 6, n. 4, p. 417-426, 1967.

GÓES, J. M.; FERNANDES-GÓES, L. C.; LEGAT, J. F. A. “Andada” do caranguejo Ucides cordatus (Linnaeus, 1763) (Crustacea, Ocypodidae) na Área de Proteção Ambiental (APA) do Delta do Parnaíba, Piauí. In: ENCONTRO DE ZOOLOGIA DO NORDESTE, 15. Resumos... Salvador: Ed. UNEB, 2005. p. 217.

GOMES, L. (Eco)turismo em Praia do Forte-BA: o descompasso entre o discurso e a prática. In: CONGRESSO NACIONAL DE MEIO AMBIENTE NA BAHIA, 1. Anais... Salvador: UFBA, 1999. p. 156-157.

HAIMOVICI, M.; KLIPPEL, S. Diagnóstico da biodiversidade dos peixes teleósteos demersais marinhos e estuarinos do Brasil. In: Workshop para avaliação e ações prioritárias para a conservação da biodiversidade 
das zonas costeira e marinha do Brasil. Relatório técnico (CD-ROM). Brasília: Ministério do Meio Ambiente, 2002.

JESUS, A.R.G.; NASCIMENTO JÚNIOR, A.F. O desenvolvimento urbano e os problemas ambientais e culturais nas comunidades pesqueiras do município de Ilha Comprida. In: CONGRESSO DE ECOLOGIA DO BRASIL, 3. Resumos... Brasília: UnB, 1996. p. 238-339.

LAGE, C.S.; LOPES, L.A. A reconquista do litoral baiano pelo turismo e as questões ambientais. In: CONGRESSO NACIONAL DE MEIO AMBIENTE NA BAHIA, 1. Anais... Salvador: UFBA, 1999. p. 315-317.

MACEDO, S.S.; PELEGRINO, P.R.M. Do Éden à cidade - transformação da paisagem litorânea brasileira. In: YÁZIGI, E.; CARLOS, A.F.A.; CRUZ, R.C.A. (orgs.). Turismo: espaço, paisagem e cultura. São Paulo: HUCITEC, 1996. p. 156-160.

MACHADO-GUIMARÃES, E.M. Impacto da urbanização sobre comunidades pesqueiras artesanais do município de Marica. In: ENCONTRO DE CIÊNCIAS SOCIAIS E O MAR NO BRASIL, 2. Coletânea de trabalhos apresentados... São Paulo: IOUSP/F. FORD/UICN, 1988. p. 92-98.

MACHADO-GUIMARÃES, E.M. A pesca tradicional em Maricá (RJ) sob uma perspectiva da ecologia cultural. 1995. Tese (Doutorado), Universidade Federal de São Carlos, São Carlos, 1995.

MAGALHÃES, H. F.; COSTA NETO, E.M.; SCHIAVETTI, A. Local knowledge of traditional firshermen on economically important crabs (Decapoda, Brachyura) in the city of Conde, Bahia State, Northeastern Brazil. Journal of Ethnobiology and Ethnomedicine, v. 8:13, 2012.

MARQUES, J.G.W. Aspectos ecológicos na etnoictiologia dos pescadores do Complexo Estuarinolagunar Mundaú-Manguaba. 1991. Tese (Doutorado), Universidade Estadual de Campinas, Campinas, 1991.

MARQUES, J.G.W. Etnoecologia, educação ambiental e superação da pobreza em áreas de manguezais. In: ENCONTRO NACIONAL DE EDUCAÇÃO AMBIENTAL EM ÁREAS DE MANGUEZAIS, 1. Anais... Maragogipe (BA), 1993. p. 29-35.

MARQUES, J.G.W. Pescando pescadores: etnoecologia abrangente no baixo São Francisco. São Paulo: NUPAUB-USP, 1995

MENDONÇA, R. Turismo ou meio ambiente: uma falsa opção ? In: LEMOS, A.I.G. de (org.). Turismo: impactos socioambientais. São Paulo: HUCITEC, 1996. p. 19-25.

MENEZES, D.L.; SANTIAGO, A.G. Ilha de Santa Catarina: paisagem litorânea em transformação. O caso da Lagoa da Conceição. In: RODRIGUES, A.B. (org.). Turismo e ambiente: reflexões e propostas. São Paulo: HUCITEC, 1997. p. 108-116.

OTT, C.F. Os elementos culturais da pescaria baiana. Bol. Mus. Nac. ser. Antrop., n. 4, 1944.

PEREIRA, E.L.; MOURÃO, J.S. Caranguejos e caranguejeiros: estudo etnobiológico de Ucides cordatus (L., 1763) (Decapoda, Brachyura). In: CONGRESSO BRASILEIRO DE ZOOLOGIA, 25. Resumos... Brasília: UNB, 2004. p. 69.

POSEY, D.A. Indigenous knowledge and development: an ideal bridge to the future. Ciência e Cultura, v. 35, n. 7, p. 877-894, 1983.

PRIMO, D.B.; SANTANA, I.; SANTOS, G.O.; DIAS, N.S. A pesca de Elasmobranchii na Área de Proteção Ambiental Litoral Norte (APA/LN), Bahia, Brasil. In: CONGRESSO BRASILEIRO DE ZOOLOGIA, 25. Resumos... 2000. p. 315.

PRIMO, D.B.; SANTANA, I.; OLIVEIRA, G.; DIAS, N.S. Importância comercial e etnoictiologia da família Ariidae (Perciformes) na Área de Proteção Ambiental Litoral Norte, Conde, Bahia, Brasil. In: ENCONTRO DE ZOOLOGIA DO NORDESTE, 15. Resumos... Salvador: UNEB, 2005. p. 482.

QUEIROZ, A. Os caminhos de Siribinha. 1997. Monografia (Bacharelado), Faculdade de Jornalismo, Universidade de São Paulo, São Paulo, 1997.

RAMALHO, C.W.N. Usos comunal e segredado como conhecimento patrimonial pesqueiro. Disponível em: <http://agreste.blogspot.com/2007/01/vii-reunio-de-antropologia-do-mercosul.html >. Acesso em: 24 abr. 2008.

RÊGO, J.C.V. Etnoecologia dos pescadores de Velha Boipeba-BA: dos costero à berada. 1994. Monografia (Bacharelado), Universidade Federal da Bahia, Salvador, 1994.

REITERMAJER, D. Comunidade extrativista do manguezal de Porto de Sauípe, Entre Rios - BA: uma abordagem ecológica e social. 1996. Monografia (Bacharelado), Universidade Federal da Bahia, Salvador, 1996.

RIST, S.; DAHDOUH-GUEBAS, F. Ethnosciences - A step towards the integration of scientific and indigenous forms of knowledge in the management of natural resources for the future. Environ. Dev. Sustain., v. 8, p. 467-493, 2006.

ROBBEN, A.C. 1982. Tourism and change in a Brazilian fishing village. Cultural Survival Quarterly, v. 6, n. 3, p. 18-19, 1982.

ROCHA, A.C.S. Às margens do Rio Cocho: um estudo de caso sobre o pequeno produtor e a preservação dos recursos hídricos na Chapada Diamantina. 2002. Dissertação (Ciências Soiais), Universidade Federal da Bahia, Salvador, 2002 
SACHS, I. Que futuro espera a Amazônia? O Correio da UNESCO, ano 20, n. 1, s. p., 1992.

SACHS, I. Em busca de novas estratégias de desenvolvimento. Estudos Avançados, v. 9, n. 25, p. 23-63, 1995.

SALLENAVE, J. Giving traditional ecological knowledge its rightful place in environmental impact assessment. Northern Perspectives, v. 22, n. 1, p. 16-18, 1994.

SANTANA, I.; JESUS, N.G.; REZENDE, J.N.; BARBOZA, D.M.; BARBOSA, M.S. A pesca artesanal na APA Litoral Norte da Bahia. In: CONGRESO BRASILEIRO DE ZOOLOGIA, 23. Resumos... Cuiabá: UFMT, 2000. p. 348.

SANTANA, I.; PRIMO, D.B.; SANTOS, G.O.; DIAS, N.S. Peixes ameaçados de extinção na pesca artesanal na Área de Proteção Ambiental Litoral Norte, Bahia, Brasil. In: ENCONTRO DE ZOOLOGIA DO NORDESTE, 14. Resumos... Maceió: UFAL, 2003. p. 300.

SANTOS, M.P.N. A pesca enquanto atividade humana: pesca artesanal e sustentabilidade. Revista da Gestão Costeira Integrada, v. 12, n. 4, p. 405-427, 2012.

SILVA, A.R.G.; COSTA-NETO, E.M. Narrativas de pescadores artesanais sobre as transformações ocorridas na pesca de peixes estuarinos da Baía de Todos os Santos, Bahia. Revista Ouricuri, v. 8, p. 58-79, 2018.

SILVA, C.C. Herança geológica como ferramenta para a prospecção de sambaquis no litoral norte do Estado da Bahia: o exemplo do sambaqui Ilha das Ostras. 2000. 126 f. Dissertação (Geologia), Universidade Federal da Bahia, Salvador, 2000.

SILVANO, R.A.M. Pesca artesanal e etnoictiologia. In: BEGOSSI, A. (org.). Ecologia de pescadores da Mata Atlântica e da Amazônia. São Paulo: Hucitec/Nepam/Unicamp; Nupaub/USP: Fapesp, 2004. p. 185-222.

SILVANO, R.A.M.; VALBO-JORGENSEN, J. Beyond fishermen's tales: contributions of fishers' local ecological knowledge to fish ecology and fisheries. Environ. Dev. Sustain., v. 10, p. 657-675, 2008.

SPRADLEY, J.P.; McCURDY, D.W. The cultural experience: ethnography in complex society. Tennessee: Kingsport Press of Kingsport, 1972.

TOLEDO, V.M. El juego de la supervivencia: un manual para la investigación etnoecológica en Latinoamérica. Santiago: Consorcio Latinoamericano de Agroecología y Desarrollo, 1991.

TOLEDO, V.M. What is ethnoecology? Origins, scope and implications of a rising discipline. Etnoecológica, v. 1, p. 5-21, 1992.

TOLEDO, V.M. Ethnoecology: a conceptual framework for the study of indigenous knowledge of nature. In: STEPP, J.R. (ed.). Ethnobiology and biocultural fiversity. Georgia: International Society of Ethnobiology, 2002. p. 511-522.

VIANNA, J.C.; REITERMAJER, D. Crescimento desordenado ameaça Litoral Norte. Baía de Todos, n. 9, p. 3, 1997. 